\title{
Bayesian Methods to Estimate Urban Growth Potential
}

Jordan W. Smith, Lindsey S. Smart, Monica A. Dorning, Lauren Nicole Dupéy, Andréanne Méley and Ross K. Meentemeyer

This manuscript is prepared exclusively for Landscape and Urban Planning

\section{Author Note}

Jordan W. Smith and Lauren Nicole Dupéy, Department of Environment and Society and Institute of Outdoor Recreation and Tourism, Utah State University, Logan, UT, USA; Lindsey S. Smart, Andréanne Méley and Ross K. Meentemeyer, Department of Forestry and Environmental Resources and Center for Geospatial Analytics, NC State University, Raleigh, NC, USA; Monica Dorning, US Geological Survey, Denver, CO, USA.

This research was supported by a grant from the National Science Foundation (\#0949170) and support from the College of Natural Resources at NC State University. Any use

of trade, product or firm names is for descriptive purposes only and does not imply endorsement by the US Government.

Corresponding author: Jordan W. Smith, Department of Environment and Society and Institute of Outdoor Recreation and Tourism, Utah State University, Logan, UT 84322. E-mail: jordan.smith@usu.edu 


\begin{abstract}
Urban growth often influences the production of ecosystem services. The impacts of urbanization on landscapes can subsequently affect landowners' perceptions, values and decisions regarding their land. Within land-use and land-change research, very few models of dynamic landscape-scale processes like urbanization incorporate empirically-grounded landowner decision-making processes. Very little attention has focused on the heterogeneous decision-making processes that aggregate to influence broader-scale patterns of urbanization. We examine the land-use tradeoffs faced by individual landowners' in one of the United States' most rapidly urbanizing regions - the urban area surrounding Charlotte, North Carolina. We focus on the land-use decisions of non-industrial private forest owners located across the region's development gradient. A discrete choice experiment is used to determine the critical factors influencing individual forest owners' intent to sell their undeveloped properties across a series of experimentally varied scenarios of urban growth. Data are analyzed using a hierarchical Bayesian approach. The estimates derived from the survey data are used to modify a spatiallyexplicit trend-based urban development potential model, derived from remotely-sensed imagery and observed changes in the region's socioeconomic and infrastructural characteristics between 2000 and 2011. This modeling approach combines the theoretical underpinnings of behavioral economics with spatiotemporal data describing a region's historical development patterns. By integrating empirical social preference data into spatially-explicit urban growth models, we begin to more realistically capture processes as well as patterns that drive the location, magnitude and rates of urban growth.
\end{abstract}

Keywords: stated choice methods; urbanization; land change; Bayesian model 


\section{Bayesian Methods to Estimate Urban Growth Potential}

\section{Introduction}

Across the globe, rapid urban expansion is impacting both the productivity of natural systems and the health of human populations. Globally, recent projections suggest that by 2030 urban land area will be 3 times larger than the extent observed in 2000 (Seto, Güneralp, \& Hutyra, 2012). Urbanization results in the loss of productive agricultural lands, fragmentation of critical habitats that support biodiversity and a reduction in the amount of carbon the biosphere can sequester from the atmosphere (Seto, Fragkias, Güneralp, \& Reilly, 2011). In the United States, recent research has demonstrated that the conversion of forests and farmlands to lowdensity built environments has compromised local ecosystems and the life-sustaining benefits these ecosystems provide (Alig, Kline, \& Lichtenstein, 2004; Brown, Johnson, Loveland, \& Theobald, 2005; Hansen et al., 2005a; Maestas, Knight, \& Gilgert, 2003; Munn, Barlow, Evans, \& Cleaves, 2002; Radeloff, Hammer, \& Stewart, 2005). These environmental consequences will become increasingly salient as the global population continues to grow and as greater proportions of the population choose to live in urban areas (Angel, Parent, Civco, Blei, \& Potere, 2011).

Despite growing concerns over the environmental consequences of rapidly growing urban areas, very little research has attempted to understand how the decisions of individual landowners affect aggregate urbanization processes. Numerous studies of urban growth have used observational data of historical development patterns (e.g., remote sensing data, property ownership records, etc.) to describe, quantify and project the location, magnitude and rates of urban growth (Seto et al., 2011; Verburg et al., 2016). Historical development trends are frequently used to measure and model urban growth patterns (Brown, Verburg, Pontius Jr, \& 
24 Lange, 2013; National Research Council, 2013). However, urbanization at its most fundamental

25 level is the result of individual landowners' decisions to sell or develop their farm- and/or

26 forestland. Urbanization is an emergent process resulting from the aggregate land-use decisions

27 of hundreds or thousands of individual landowners and their interactions with their environments

28 (Alberti, 2010; Verburg et al., 2015).

29 The land-use decisions of landowners in urbanizing regions are influenced by multiple,

30 often conflicting, factors. Urban development commonly results in an increase in the market

31 value of nearby agricultural and forest lands (Bastian, McLeod, Germino, Reiners, \& Blasko,

32 2002; Delbecq, Kuethe, \& Borchers, 2014; Guiling, Brorsen, \& Doye, 2009). Consequently,

33 owners of those agricultural and forest lands may welcome nearby urban development, seeing it

34 as a way to expand the value of their properties. However, most small non-industrial agricultural

35 and forest owners in the United States do not manage their properties for financial reasons.

36 Rather they value the aesthetic, cultural, recreational and social benefits provided by owning a

37 working farm or an unmanaged forest stand (Silver, Leahy, Weiskittel, Noblet, \& Kittredge,

38 2015). Nationwide survey data suggest non-industrial private forest owners tend to rate financial

39 objectives for owning woodlands less important than amenity-related objectives such as

40 desirable landscape aesthetics, providing habitat for wildlife or protecting nature (Butler et al.,

41 2016). If landowners place more value on the non-monetary uses of their properties, it is likely

42 they would perceive encroaching development and rising property values as a burden. Nearby

43 development can directly affect landowners' ability to achieve the aesthetic, cultural, recreational

44 and social benefits, which they value most. As development encroaches and property values rise,

45 property taxes also increase which can create a financial burden on landowners who do not

46 manage their properties for income generation (Butler et al., 2012; Greene et al., 2014; Ma et al., 
47 2014). These are the difficult tradeoffs faced by landowners in rapidly urbanizing regions. These

48 complex and multi-faceted decisions are the most fundamental mechanism of the urbanization

49 process.

50 It is important to note at this point that not all urbanization is driven by the sovereign

51 decisions of landowners. Development can occur through direct state intervention. In the United

52 States for example, eminent domain has allowed city governments to expropriate private

53 property for public use via compensating payments (Epstein, 2013). Similarly, compulsory

54 purchase orders, used in the United Kingdom, Ireland, Taiwan and developing countries are a

55 legal mechanism through which ownership of private property can be transferred if it is deemed

56 to be in the public interest (Adu-Gyamfi, 2012; Denyer-Green, 2013; Lin \& Lin, 2006). With

57 these exceptions, the predominant method through which urbanization occurs is via the

58 aggregation of individual landowners' decision to sell their farmland and/or forestland.

59 In this research, we explicitly examine the factors driving individual landowners' land-

60 use decisions in one of the United States' most rapidly urbanizing regions - the urban area

61 surrounding Charlotte, North Carolina. Our investigation focuses on the land-use decisions made

62 by non-industrial private forest owners spread across the region's development gradient. A

63 discrete choice experiment is used to determine the critical factors influencing individual forest

64 owners' intent to sell their properties across a series of experimentally varied development

65 scenarios. Data are modeled with a Bayesian hierarchical model. The choice experiment model

66 yields estimated posterior distributions for each of the experiment's attributes. We use these

67 estimated posterior distributions to inform a subsequent hierarchical spatial model, the

68 development potential model, which predicts the potential of each parcel within the study area to

69 be developed based upon historical development patterns and parcel-specific attributes which 
70 match the attributes presented to forest owners in the choice experiment (current distance to

71 development, property value and qualification for a tax-relief program). The linked modeling

72 approach, enabled through the use of Bayesian estimation techniques, allows us to generate

73 spatially-explicit estimates of development potential that are informed by primary data collected

74 from the forest owners whose future land-use decisions will affect how and where urbanization

75 occurs throughout the study area. We show that urban growth is an aggregate product of human

76 decisions, which are themselves a function of how individuals evaluate competing factors

77 associated with encroaching development. Our research demonstrates that carefully developed

78 and rigorously employed social science research can be used to inform projections of the

79 location, magnitude and rates of urban growth.

Related Literature

\section{The Effect of Urbanization on Forest Property Values}

83 Economic theory suggests the value of land is determined by the net present value of

84 expected future returns (Chavas \& Thomas, 1999). For forested properties, expected future

85 returns can be influenced by the proximity to viable timber markets, accessibility to city centers

86 and future rent increases resulting from an increased demand for land (i.e., population growth)

87 (Capozza \& Helsley, 1989). Rising property values resulting from the increased demand for land

88 is most notable near or at the boundaries of urban areas (Delbecq et al., 2014). In a national study

89 measuring the determinants of agricultural land values, Plantinga et al. (2002) found that as

90 much as $80 \%$ of a property's market value is attributable to expected development rents. This

91 proportion tends to rise as urban areas expand and the total amount of developable lands

92 diminishes (Bastian et al., 2002; Guiling et al., 2009; Wear \& Newman, 2004). Consequently, 
93 forest owners living near rapidly urbanizing regions are facing difficult decisions regarding

94 whether they retain the current use of their forest lands (e.g., harvesting for timber, recreational

95 and/or aesthetic enjoyment, etc.) and pay increasing property taxes, or decide to sell to

96 developers (Butler et al., 2012; Greene et al., 2014; Ma et al., 2014).

97 While there has been a large body of empirical work examining the factors and effects of

98 urbanization on property values, most of this research has focused on agricultural land values

99 and has used hedonic pricing methods. To our knowledge, only one study has used stated choice

100 experiments to examine the factors influencing forest landowners' decision to sell. Stated choice

101 experiments allow researchers to explore the extent to which forest owners' decisions regarding

102 their properties are influenced by rising property values (if at all) relative to other important

103 factors such as the owners' financial and management objectives. Rozance and Rabotyagov

104 (2014) administered a stated preference survey to small Washington forest landowners in order

105 to gauge their intent to sell their forested properties based on perceptions of existing and future

106 development pressures and the timing of such development. The study concluded that forest

107 owners who managed their land as 'a sound financial investment' were more likely to anticipate

108 developing their forestlands in the near future. Conversely, forest owners who indicated

109 managing their land for either 'aesthetic enjoyment' or as 'a place for wildlife' were less likely to

110 anticipate developing their forestland, even after controlling for the proximity of future

111 development. Additionally, owners of larger forests were significantly more likely to anticipate

112 developing their forestland in the near future. Rozance and Rabotyagov also determined the

113 likelihood of development decreased by $15 \%$ for every mile a forest owners' property was from

114 development. Similarly, forest owners living nearer to developed areas were more likely to 
115 indicate developing their properties sooner (for every mile a forest owner's property was from

116 development, the estimated time to development decreased by $2 \%$ ).

117 Given the findings of Rozance and Rabotyagov (2014), as well as the large body of

118 literature focused on quantifying the effects of urbanization on property values, we expect

119 increased property values will positively influence the likelihood of forest owners around the

120 Charlotte metropolitan area indicating an intent to sell his/her forest land. This expectation is

121 guided by the assumption that landowners are profit seeking entities who will capitalize on the

122 rising property values that accompany encroaching urban development by selling their own land.

123

124 Negative Consequences Associated with Urban Development

125 In addition to the rising tax burden faced by forest owners whose properties are in

126 urbanizing regions, urbanization also results in a variety of other undesirable environmental

127 consequences which may influence forest owners' decision to retain or sell their property. Some

128 of these impacts include habitat fragmentation, decreased air quality, diminished water quality

129 and quantity as well as the introduction of exotic plant species and reductions in native species

130 richness (Bhatta, 2010; Hansen et al., 2005b). Urban development also commonly results in

131 increased traffic congestion, which can reduce personal time and impact psychological health

132 (Brueckner, 2000; Frumkin, 2002). Urban growth is also associated with degraded landscape

133 aesthetics, which may be particularly salient for forest owners (Erickson, Ryan, \& De Young,

134 2002) and rural residents (Milburn, Brown, \& Mulley, 2010) who tend to value and maintain

135 their forest land for aesthetic instead of monetary reasons. The diverse array of evidence

136 suggesting urbanization has negative ecological and social/psychological impacts provides

137 further support that distance to urban development will negatively influence the likelihood of an 
138 individual indicating an intent to sell his/her forest land. That is, the further a forest owner's

139 parcel is from existing development, the less likely they would be to indicate intent to sell it for

140 development.

141 Given the findings of the large body of literature focused on quantifying the negative 142 consequences of urbanization for existing agricultural and forest landowners, we expect greater

143 distances to urban development will be negatively related to the likelihood of an individual

144 indicating an intent to sell his/her forest land. This expectation is guided by the assumption (and

145 empirical data) that non-industrial forest owners' land-use decisions are influenced by their

146 desire to maintain desirable aesthetic and non-market benefits from their forested lands. As

147 urbanization encroaches and those benefits diminish, these landowners will receive less utility

148 from ownership and subsequently sell their properties.

\section{Alternative Property Tax Mechanisms}

151 While the distance between a forest owners' property and nearby urban development is

152 likely to influence their property values as well as their intent to sell their forest land, the extent

153 of this influence may be mitigated by qualifying for specific tax-relief programs. In North

154 Carolina, property is traditionally assessed at market value. However, agricultural, forest and

155 horticultural lands can also be valued at present use, which is based on their ability to produce

156 income under management (PUV is calculated by dividing net return by the

157 capitalization/discount rate) (North Carolina Department of Revenue, 2015). Present-use values

158 are generally substantially lower than market value, which can offer a significant tax reduction to

159 qualifying private landowners. North Carolina's present-use value program is one of many

160 policies that aim to reduce the negative externalities caused by land-use changes, via slowing 
161 rural land conversion, encouraging reforestation and sustainable management practices

162 (Polyakov \& Zhang, 2008). However, several previous studies have concluded that present-use

163 value programs only delay land conversion, because many property owners prefer long-term

164 capital gains (Anderson, 2012; Polyakov \& Zhang, 2008). Additionally, landowners may find it

165 beneficial to sell portions of their property when faced with increased tax burdens (Poudyal \&

166 Hodges, 2009). Other problems with the efficacy of present-use value programs include low

167 awareness and, subsequently, low enrollment rates (Williams, Gottfried, Brockett, \& Evans,

168 2004). Low enrollment rates are due to a number of factors, including minimum acreage and

169 forest management plan requirements.

170 Despite the limitations noted in previous examinations and/or reviews of present-use

171 value programs, they do offer a mechanism through which forest owners can mitigate some of

172 the unwanted consequences associated with nearby urban development, namely rising property

173 taxes. Given this, we expect the ability of properties to qualify for the present-use value program

174 will decrease the likelihood that forest owners will intend to develop them.

175 Collectively, this study examines the influence of: 1) rising property values; 2) distance

176 to new urban development; and 3) the ability of properties to qualify for a tax-relief program on

177 forest owners' intent to sell their properties for development. These influences are examined

178 through the use of a discrete choice experiment delivered via a mail survey to forest owners

179 living in the rapidly growing urban areas surrounding Charlotte, North Carolina, USA. The

180 results from the choice experiment are subsequently integrated into a spatial model predicting

181 development potential across the study region. By linking estimates derived from the choice

182 model to an established model of development potential (Meentemeyer et al., 2013), we are able

183 to develop spatially-explicit maps of development potential that are directly and empirically 
184 informed by a representative sample of the forest owners who will shape the region's future 185 through their land-use decisions.

\section{Materials and Methods}

\section{Definitions}

Throughout this paper we use the term 'urbanization' to refer to the process of population concentration that occurs through either an increased number of individuals living within one

191 urban area or the increase in the total number of urban areas within a defined geographic extent

192 (Tisdale, 1942). Relatedly, 'urban growth' refers to the spatial expansion of urban areas,

193 occurring most often through the conversion of agricultural or forested areas to residential and

194 commercial land uses (Seto et al., 2014). More generally, 'land-use change' refers to the

195 conversion of a spatial area from one dominant land-use type (e.g., agriculture) to another

196 dominant land use type (e.g., residential development). 'Urban potential' refers to the likelihood

197 that a spatial area (e.g., a parcel or the area within the geographic boundaries of a pixel) will be

198 converted from an agricultural or forested land use to a residential or commercial land use based

199 on historical development patterns and population projections (Meentemeyer et al., 2013).

\section{Study Region}

The city of Charlotte, North Carolina and its surrounding metropolitan areas are located

203 in the middle of the United States' third largest "mega-region” (Florida, Mellander, \& Stolarick, 204 2008). Our study area consisted of the six counties within North Carolina surrounding the city

205 (Figure 1). The region is currently home to more than 1.6 million people (U.S. Census Bureau, 206 2015). However, that number is expected to increase by nearly $40 \%$ over the next 20 years with 
2072035 population projections at nearly 2.3 million (NCOSBM, 2015). Most development within

208 the region over the past 30 years has occurred through disjunct, low-density development leading

209 to a loss of both agricultural and forest lands. Region-wide projections suggest that under current

210 growth trajectories, over 200,000 ha of agricultural and forest land will be converted to

211 development by the year 2030 (Meentemeyer et al., 2013).

212

[FIGURE 1]

214

215

The land-use decisions made by small-scale non-industrial private forest owners play a

216 large role in shaping what the region's landscapes will look like in the future, since the majority

217 of undeveloped land throughout the region is held by these forest owners (Figure 2b). Most

218 forest owners throughout the region do not manage their properties for income generation, which

219 leaves many of them struggling to find the financial resources needed to meet growing property

220 tax burdens; less than $30 \%$ of the non-industrial private forest owners within the study area

221 qualify for the North Carolina present-use value program (Figure 2b). The landscapes of the

222 Southern Piedmont are also historically and culturally important, being some of the first non-

223 coastal landscapes settled in the early 1700s (Blythe \& Brockmann, 1961). Many forest owners

224 living throughout the region today attach strong emotional and psychological meanings to the

225 landscapes they and their families have lived on for centuries (BenDor, Shoemaker, Thill,

226 Dorning, \& Meentemeyer, 2014). These strong emotional and psychological meanings may

227 cause forest owners to hold on to their properties, even if it is not financially logical to do so. To

228 explicitly and experimentally evaluate how forest owners weigh the tradeoffs associated with 
encroaching development pressure, we designed and administered a discrete choice experiment to a representative sample of forest owners living around Charlotte's urban fringe.

[FIGURE 2]

\section{Discrete Choice Experimental Design}

Econometric Model of Forest Owners' Intent to Sell. There are a variety of methods to

237 quantify the value forest owners ascribe to their properties; some of which rely on revealed

238 preferences (i.e., their observed behaviors such as selling or leasing their forest land (e.g., Adams

$239 \&$ Turner, 2012)) and others which rely on forest owner's stated preferences to alternative

240 hypothetical scenarios. Stated preference studies are particularly appealing to economists

241 studying land use planning issues because they provide the opportunity to measure forest

242 owners' preferences to a variety of future policy and land use scenarios. Stated preference

243 methods are grounded in the idea that if changes in forest ecosystems can be represented by a set

244 of attributes, choices by forest owners among sets of alternatives can yield insightful information

245 about which potential policies or land use patterns would yield the most benefit to forest owners

246 (Holmes \& Boyle, 2003). The stated preference method we employed here was a relatively

247 simple discrete choice experiment (Louviere, Hensher, \& Swait, 2000)

248 The discrete choice experiment involved presenting forest owners with a series of

249 hypothetical scenario pairs, asking them to carefully consider the conditions described in each

250 scenario and then make a decision about under which scenario they would most likely sell their

251 property. Given land-use change within our study area is dominated by the development of 
252 agricultural and forest land (BenDor et al., 2014; Singh, Vogler, Shoemaker, \& Meentemeyer,

253 2012), we assume an intent to sell will result in the conversion of the property to either a

254 residential or commercial land use. Each scenario presented three attributes:

255

256

267 such that

268

269

270

$U_{i j t}=V_{i j t}+\varepsilon_{i j t}$
(Equation 1)

274 the design of our discrete choice experiment is relatively simple. It does not account for the 
275 different types of development that might be encroaching upon a forest- or farm-owner's

276 property. Development can range from low-density residential development to mixed-use

277 residential/commercial space to high-density commercial construction. Rather than being a

278 limitation, we feel this ambiguity allowed respondents to determine for themselves, what type of

279 development would most likely occur near their property. Additionally, given the context of our

280 study we were focused exclusively on individuals' intent to sell their property for development.

281 Other research has quantified the probability of landowners' managing their land for are variety

282 of different land uses (e.g., agricultural production, pasture, forest, rangeland and urban

283 development) (Lubowski, Plantinga, \& Stavins, 2006, 2008). Quantifying conversion functions

284 for multiple land-use types, as opposed to the undeveloped/developed dichotomy that we focus

285 on here, and then coupling those empirically-grounded functions with an urban growth model

286 capable of handling them would be a significant advancement to land change science.

287 Experimental Design, Attributes and Levels. The experimental design involved

288 varying two of the attributes $\Delta$ property_value and distance_to_development across three levels

289 and varying the third attribute puv_qualify across two levels (Table 1). Consequently, there were

$2903^{2} \times 2^{1}=18$ total possible hypothetical scenarios. We deemed it too burdensome to have forest

291 owners respond to 9 scenario pairs, subsequently opting for a fractional factorial design

292 including 6 scenario pairs. The choice of which scenarios to include in the final experimental

293 design were guided by the strategies presented by Louviere et al. (2000). 
Immediately prior to the presentation of the discrete choice pairs, forest owners were

298 informed that we were "interested in the factors that influence individuals' decision to sell or

299 hold their wooded land, including how property values, proximity to new development and

300 present-use value programs affect woodland owners' decisions, if at all." Respondents were then

301 provided with a brief narrative of what "new development" referred to and what present-use

302 value programs are; the full instrument is shown in Figure 3.

[FIGURE 3]

\section{Data Collection}

Data were collected via two self-administered mail-back surveys sent to a sample of small-scale non-industrial private forest owners living within the study area (Figure 2a). To be

309 included in the sample, forest owners must have owned more than 2 ha of contiguous forest

310 (determined via analysis of 2011 Landsat and LiDAR data (Singh et al., 2012)). The first survey

311 was focused explicitly on forest owners' beliefs (e.g., their sense of place), their past behaviors

312 and their sociodemographic characteristics. The second survey only delivered the discrete choice

313 experiment. The first survey was administered between November 2011 and April 2012 to 143

314 forest owners while the second survey was administered in November 2013 to the 126 forest

315 owners who completed the first survey. Both survey packets mailed to respondents included a

316 personalized map showing the forest owner's property. A cover letter was also attached asking

317 forest owners to respond to the questions in reference to their individual wooded land (excluding

318 other forested land they might have owned). We included these explicit instructions to help

319 ensure respondents felt they had a vested interest in the outcome of the choice question. 
Of the 126 forest owners who received the discrete choice experiment, 64 completed and

321 returned the instrument. This $49.6 \%$ response rate is acceptable for mail surveys administered to

322 the general public or landowners (Dillman, Smyth, \& Christian, 2008). Five forest owners

323 indicated their property had been sold since they responded to the first mail-back survey two

324 years earlier. All analyses were completed on data collected from the remaining 59 forest

325 owners.

327 Sample Characteristics

328 Characteristics of Forest Owners and their Properties. Summary statistics describing

329 the sample's sociodemographic characteristics and the characteristics of their properties are

330 shown in Table 2 for reference. Although our sample of landowners had similar characteristics to

331 those of the broader population of private forest owners nationwide, they do appear to be more

332 educated (Butler et al., 2016).

\section{[TABLE 2]}

Sense of Place. Jorgensen and Stedman's (2006) 12-item psychometric scale was

337 included in the first survey to measure forest owners' psychological connections to wooded areas

338 on their property. On average, forest owners indicated they hold strong personal meanings

339 towards their wooded land as responses to the statement items, which were measured on a 5-

340 point Likert scale, ranged from 2.53 to 3.92 (Table S1). We analyzed data obtained via the scale

341 for reliability (Cronbach's $\alpha>0.70$; Nunnally \& Bernstein, 1994) and adequate factor loadings

342 ( $\lambda>0.60$; Hair, Black, Babin, \& Anderson, 2009). With these psychometric properties satisfied 
343 (reported in Table S1), we calculated a single sense_of_place factor score for inclusion in 344 subsequent regression analyses.

346 Analysis

347 Bayesian Analysis. We populated the design matrix $V$ in Equation 1 with the three

348 variables directly included in the discrete choice experiment as attributes (_property_value, 349 distance_to_development and puv_qualify). We also populated the matrix with the age and 350 income of the forest owner, the sense_of_place construct and the total size of the wooded areas 351 on their property. Age and income were included as controls, given previous analyses of these 352 data has revealed age to be a significant predictor of both forest owners' willingness to allow 353 woody biomass to be harvested from their properties (Dorning, Smith, Shoemaker, \& 354 Meentemeyer, 2015) and their willingness to opt into a voluntary payments for carbon storage 355 program (Smith et al., 2016).

356 We fit the inferential model using a Bayesian hierarchical mixed effects regression 357 model. Bayesian analysis assumes all unknown parameters of interest are random, and can 358 consequently be informed and updated through prior information (Bernardo \& Smith, 2000).

359 This assumption contrasts frequentist analysis in which unknown parameters are assumed to be 360 fixed. Bayesian analysis utilizes the Bayes rule to generate posterior distributions of unknown 361 parameters by updating observed data with prior information or assumptions about the 362 distribution of those parameters (Tanner \& Wong, 1987). The posterior distributions are 363 proportional to a combination of the observed data and some prior knowledge (posterior $\propto$

364 likelihood $\times$ prior). Estimates of the posterior distribution are updated through Markov chain 365 Monte Carlo (MCMC) sampling of the prior distribution. MCMC sampling is required because 
Bayesian estimators (e.g., posterior means and standard deviations) cannot be simultaneously

367 derived through closed form integration (Bernardo \& Smith, 2000). Parameters describing

368 posterior distributions (e.g., means and interval estimates) are updated at each MCMC

369 simulation. Once the MCMC sampling converges, typically after several thousand simulations,

370 the parameters describing the posterior distribution can be assumed stable. Formal hypotheses

371 are tested in Bayesian analysis through interval-hypothesis testing where the probability that an

372 estimated parameter of the posterior distribution fits within an particular interval range is

373 evaluated (Carlin \& Louis, 2008).

374 Choice Experiment Model Specification. Our inferential logistic regression model, 375 grounded in random utility theory and the estimation of the random utility function (Equation 1)

376 is formally specified as:

$$
U_{i j t}=a_{i j}+\sum_{j}^{3} \beta v_{i t}+\beta z_{i}+\varepsilon_{i j t}
$$

380 In Equation 2, $U_{i j t}$ is the utility individual $i$ receives from choosing $j$ (a preference to sell their 381 forested property) in scenario $t . \alpha_{i j}$ is the respondent specific intercept for alternative $j$ arising 382 from individual $i$ 's unobserved preferences. The $\beta$ 's are the vectors of estimated coefficients, 383 which do not vary over individuals or choice occasions, related to the vectors of $v$. These vectors 384 are simply the levels corresponding to the three attributes $j$ (Aproperty_value, 385 distance_to_development and puv_qualify). We also include a set of individual-level vectors $z$ 386 (age, income, sense_of_place and forested_acres) as controls; each of these are associated with 387 an estimated coefficient $\beta$. 
Using a Bayesian approach, we must assume a distribution for all of the coefficients of interest $(\beta \mathrm{s})$. We assume prior distributions for all fixed effects coefficients are normally

390 distributed, centered on zero $(\mu=0)$ with large variance $\sigma^{2}=10 \mathrm{e}^{10}$; this is common in Bayesian 391 applications (Hadfield, 2010). The prior for the variance structure was drawn from an Inverse-

392 Wishart distribution with expected (co-)variances set to one and the degree of belief parameter

393 set to zero. We also fit a hierarchical logistic regression using a frequentist approach for 394 comparison.

Development Potential Model Specification. Our primary motivation for adopting a Bayesian approach is that it provides an opportunity to use parameter estimates derived from the

397 choice experiment as informative priors in a subsequent spatial model which predicts the 398 potential of each parcel within the study area to be developed based upon historical development 399 patterns and parcel-specific attributes which match the attributes presented to forest owners in 400 the choice experiment. The development potential model is a geospatial hierarchical statistical 401 model with a binary response variable corresponding to lands that transitioned between 402 undeveloped and developed between 2000 and $2011(0=$ developable land that did not develop 403 during the 11-year time period; 1 = developable land that did develop during the 11-year time 404 period). This response variable was constructed using National Land Cover Database datasets 405 and was fit using a stratified random sample of 1,724 grid cells (866 transition cells, 862 no 406 change cells), distributed across the six county study area. The development potential model for 407 this region was originally introduced by Meentemeyer et al. (2013) and fit to a stratified-random 408 sample of 1,450 grid cells distributed across the 11 counties surrounding the Charlotte urban area 409 for the years 1996-2006. There were five predictors of development in the original development 410 potential model; these are described in Table 3. 


\section{[TABLE 3]}

In this paper, we update the original development potential model by: 1) fitting it to

415 parcel data (as opposed to pixel data); 2) introducing additional independent variables believed

416 to influence forest owners' decisions regarding whether or not they will sell their property for

417 development; and 3) informing those additional variables (via prior distributions) with the

418 parameters estimated by the choice experiment model described above.

419 The additional independent variables introduced into the development potential model are

420 distance to new development (distance_to_development), property value (property_value) and

421 qualification for the North Carolina present-use value program (puv_qualify). These variables are 422 described, and their data sources are detailed, in Table 3.

423 To examine and illustrate the influence of informing the development potential model

424 with informative priors generated by a choice experiment, we re-estimated the pixel-based model

425 introduced in Meentemeyer et al. (2013) with the additional independent variables believed to

426 affect forest owners' decisions. Next, we fit the model to parcel data acquired for the same

427 temporal span (2000 to 2011) as the data used to fit the pixel-based model. The model was fit

428 with a hierarchical Bayesian mixed-effects logistic regression estimation procedure. All

429 parameters were estimated using noninformative priors (explained in the Choice Experiment

430 Model Specification section). Finally, we fit the development potential model to just those

431 parcels that comprised the survey's sampling frame (Figure 2b). We used the same hierarchical

432 Bayesian mixed-effects logistic regression estimation procedure. This model, however, used

433 prior distributions generated from the choice experiment model on a subset of the fixed effects 
434 predictor variables (the spatial analogues of the scenario attributes in the choice experiment).

435 Specifically, the priors were: Aproperty_value $(\bar{\mu}=1.719) ;$ distance_to_development $(\bar{\mu}=$

$436-0.446)$ and puv_qualify $(\bar{\mu}=-0.251)$. Following Bayes' rule, the posterior distribution of all

$437 \beta$ s is estimated by combining the assumed prior distributions and the observed parcel data $\mathrm{y}$; this

438 is expressed as:

439

$440 \quad f(\beta \mid y)=\frac{f(\beta) f(y \mid \beta)}{f(y)}$.

(Equation 3)

442 The numerator is the joint density of the observed data and the prior distribution and the

443 denominator is the distribution of the observed data (Hosmer, Lemeshow, \& Sturdivant, 2013).

444 The posterior distribution was estimated using the Metropolis-Hastings algorithm and Gibbs

445 sampling, a common and efficient method of MCMC sampling (Casella \& George, 1992). All

446 statistical analyses were performed using the MCMCglmm package in R (Hadfield, 2010;

447 Knudson, 2015).

\section{Results}

450 Choice Experiment Model

451 Before moving to inference, we assessed the convergence of the MCMC simulations by

452 visually inspecting the movement of each coefficient of interest throughout the 200,000 MCMC

453 iterations (the plots are illustrated in Figure 4). Across all estimated coefficients, the trace plots

454 exhibited no evidence of non-stationarity (trend). Additionally, the between-run autocorrelations

455 (not shown) trailed off quickly, suggesting good mixing of the chain. 
[FIGURE 4]

460 regression specification are shown in Table 4. The results of the Bayesian specification revealed 461 changes in each of the choice experiments attributes resulted in notable effects on forest owners'

462 intent to sell their properties. When a scenario described an increase in property values, the 463 estimated posterior mean was 1.719; the odds of a forest owner selling their property are nearly 6 464 times higher if their property value were to increase by at least $10 \%$ from its current value (Odds $465 \quad$ ratio $\left.=\exp ^{1.719}=5.58\right)$.

Forest owners were less motivated by encroaching development, as shown by the smaller

470 absolute value of the estimated coefficients for the distance_to_development variable compared

471 to the Aproperty_value variable. The sign of the estimated distance_to_develoment coefficient

472 was negative, suggesting development closer to a forest owner's property is positively correlated

473 with the probability of indicating an intent to sell their property. Effect size measures for the

474 distance_to_development variable was -0.446, suggesting nearer development actually has a

475 positive and linear effect on individuals' intent to sell their properties.

476 Qualifying for a present-use value program does not appear to have any meaningful

477 influence on forest owners' intent to sell their properties. The mean of the posterior distribution 478 of the puv_qualify variable was -0.251 with 0 within the $95 \%$ credible interval. 
The emotional and psychological meanings individuals hold towards their forested property (sense_of_place) does not appear to influence their intent to sell their properties. The mean of the posterior distribution was -0.692 with 0 within the $95 \%$ credible interval. The results

482 also suggested neither age, income or the number of forested acres on individuals' properties 483 significantly influenced the probability of forest owners' indicating an intent to sell their 484 property; zero was within the $95 \%$ credible interval for all three of these predictor variables.

\section{Development Potential Model}

All results presented below are for the updated development potential model, which includes the additional independent variables believed to influence forest owners' decisions regarding whether or not they will sell their property for development (distance_to_development, property_value, puv_qualify). Our first estimation was fit to all pixels (i.e., undeveloped in 2000)

491 distributed across the six-county study region; the results of this model are presented in Table 5.

492 The results revealed a negative correlation between the probability of a cell becoming developed

493 and the distance to roads variable and a positive correlation between development and the

494 development pressure variable (i.e., the number of neighboring developed cells within a search

495 distance weighted by distance). Cells closer to roads existing in 2000 were more likely to be

496 developed. Similarly, undeveloped cells with more development nearby were more likely to be 497 developed. The results also revealed that the distance between an undeveloped cell and new 498 development (i.e., new development in 2000) was negatively correlated with the probability of 499 that cell becoming developed. Finally, the model revealed grid cells that fell within parcels 500 which qualified for the North Carolina present-use value program were less likely to be 501 developed in 2011 relative to those which did not qualify. The predicted probabilities of 
502 development for all qualifying pixels within the study region are shown in Figure 5c. For

503 comparison, the predicted probabilities of development estimated with the original Meentemeyer

504 et al. (2013) model (i.e., minus the three additional explanatory variables), is shown in Figure 5b.

[TABLE 5]

\section{[FIGURE 5]}

511 distributed across the six-county study region; the results of this model are presented in Table 6.

512 The results were similar to the model fit to all pixels. Specifically, we noted a negative

513 correlation between the probability of a parcel becoming developed and the distance to roads

514 variable, and a positive correlation between development probability and the development

515 pressure variable. Similarly, the model revealed a negative relationship between the distance to 516 newly developed parcels and a property becoming developed by 2011. Parcels that qualified for

517 the present-use value program in 2000 were also less likely to be developed by 2011 . Predicted 518 probabilities of development for all qualifying parcels within the study region are shown in 519 Figure 5d. 
525 least 2 ha of forested area on their properties. This estimation used the parameter estimates

526 derived from the choice experiment model as informative priors. The results, shown in Table 7 ,

527 were similar to both the pixel based model and the parcel based model fit to all properties within

528 the study region. Distance to roads showed a negative correlation with development probability

529 and development pressure showed a positive relationship with development probability. Non-

530 industrial private forestlands further away from new development as well as those which did not

531 qualify for the present-use value program were less likely to be developed.

[TABLE 7]

Figure $6 \mathrm{~b}$ shows a close-up of the predicted probabilities of derived from the parcelbased development potential model fit with non-informative priors. Figure 6c shows a close-up

537 of the predicted probabilities of derived from the parcel-based development potential model fit

538 with informative priors for all qualifying parcels owned by non-industrial private forest owners.

539 Finally, Figure 6d shows the difference between the parcel-based surface derived using non-

540 informative priors and the parcel-based surface derived using informative priors for all

541 qualifying parcels owned by non-industrial private forest owners. A simple subtraction between

542 the two surfaces (the development potential surface estimated with informative priors for all

543 qualifying parcels owned by non-industrial private forest owners minus the development

544 potential surface estimated for all parcels using non-informative priors) illustrates the differences

545 obtained through the use of the linked modeling approach. Warmer colors represent qualifying

546 parcels owned by non-industrial private forest owners that were mapped as having higher

547 development potential when informative priors were used and cooler colors represent parcels 
548 owned by non-industrial private forest owners that were mapped as having lower development

549 potential when informative priors were used. Though the differences are small, by using parcel-

550 level information in addition to choice experiment data informed by respondent preferences, we

551 see more heterogeneity than in the pixel-based models of development potential. In areas with

552 high property values, as well as in areas that are closer to development, we start to see

553 divergence in development potential between parcels owned by non-industrial private forest

554 owners and parcels owned by other types of landowners.

[FIGURE 6]

\section{Discussion}

The first objective of this research was to empirically quantify how forest owners in a

560 rapidly urbanizing region make decisions when faced with encroaching development. To date,

561 relatively little research has attempted to address this question. There undoubtedly has been a

562 large body of empirical research focused on quantifying the effects of urbanization on property

563 values using revealed preference data such as property transaction data and public tax records

564 (most of this work comes from the fields of agricultural and natural resource economics). This

565 research however, fails to acknowledge that forest owners' decisions are driven by a variety of

566 factors besides the well-documented rise in property values (and taxes) that accompany urban

567 encroachment. These factors can include the heterogeneity in forest owners' perceptions of

568 encroaching development, as many may not perceive, understand or value the impacts that urban

569 expansion has on the production of ecosystem services. These factors can also include the

570 availability of land-use policies, such as alternative property tax mechanisms, designed to 
571 alleviate the rising financial burdens faced by individuals who may not want to sell their forested

572 properties. Logically, these factors can also include forest owners' sociodemographic

573 characteristics (household income being foremost among them) as well as the psychological

574 attachments they hold towards their properties. To measure each of these characteristics, and

575 more importantly quantify their influence on forest owners' land-use decisions, a broader suite of

576 social science methodologies needs to be employed. Recent research has begun to utilize stated

577 preference data, collected through surveys administered to forest owners, to develop a more

578 holistic understanding of what drives forest owners' land-use decisions when faced with nearby

579 urban development (Rozance \& Rabotyagov, 2014). Our research builds upon this emerging

580 body of knowledge through the application of a discrete choice experiment delivered explicitly

581 to the non-industrial private forest owners whose individual decisions will shape the trajectory

582 and spatial patterns of urban growth within one of the United States' most rapidly growing

583 mega-regions, the areas surrounding Charlotte, North Carolina.

584 Using data collected from a sample of forest owners living throughout the region, our

585 choice experiment model revealed rising property values positively influenced the probability of

586 a forest owner indicating he/she would sell his/her property. This result was expected given most

587 non-industrial private forest owners in the United States do not manage their properties for

588 income generation (Butler, 2008), making them especially vulnerable to fluctuations in property

589 values and property tax rates (Butler et al., 2012; Greene et al., 2014; Ma et al., 2014). Our

590 sample of forest owners were similar to the broader population of forest owners throughout the

591 nation in that the vast majority $(71 \%)$ indicated they did not manage their property for income-

592 generating purposes (Butler et al., 2016). This result is also consistent with Rozance and 
593 Robotyagov's study of forest owners' intent to develop their forested properties in the Pacific

594 Northwest (2014).

Our choice experiment model also revealed the closer that development occurred to an

596 undeveloped and forested property, the more likely the owners of that property would be to sell.

597 This result was also expected given our assumption and previous empirical research (Bengston,

598 Asah, \& Butler, 2010; Kilgore et al., 2015; Majumdar, Laband, Teeter, \& Butler, 2009) which

599 suggests non-industrial private forest owners highly value the more 'rural' and 'natural'

600 landscapes which surround their properties. While our data do not allow us to explicitly state that

601 forest owners associate nearby development with a loss of valued ecosystem services, the

602 random utility framework which grounds our model's specification enables us to infer that new

603 development closer to a forest owner's property results in a substantial and negative impact on

604 the value (or more explicitly put, utility) which he/she derives from owning his/her property.

605 More focused research is needed to explicitly determine which ecosystem services (e.g., carbon

606 sequestration, wildlife habitat, clean water, etc.) forest owners in urbanizing regions value most.

607 This work would enable the development of focused policies, specifically payments for

608 individual ecosystem services that would tap into forest owners' motivations for owning their

609 land while simultaneously providing them with some monetary relief from the rising property

610 values.

611 Our choice experiment model also revealed qualifying for the North Carolina present-use

612 value program did not have a substantial influence on forest owners' intent to sell their

613 properties. This result may not be particularly surprising given the program was not explicitly

614 designed as a mechanism to limit urban growth. Rather, the program provides the opportunity to

615 ease the tax burden of forest owners if they agree to and implement a forest management plan for 
616 the woodlands on their property. These management plans often involve harvesting operations

617 that, while providing an additional revenue stream for forest owners, do not align with the values

618 they attach to their lands and their motivations for ownership. Tax-relief programs like the North

619 Carolina present-use value program may be effective at achieving their intended goal of reducing

620 the property taxes paid by forest owners while simultaneously bolstering the state's forestry

621 industry, however our results indicate they are not effective at influencing the decision-making

622 process related to selling private forestlands for development. In rapidly urbanizing regions, like

623 our study area, progressive land-use policies are needed that meet all three objectives: reducing

624 the burden of rising taxes faced by private forest owners; supporting local and regional forestry

625 industries which tend to stagnate or decline as urban areas consume harvestable woodlands

626 (Stein et al., 2005); and providing flexibility in allowing forest owners to choose how their forest

627 lands are managed (i.e., not explicitly requiring harvesting). To our knowledge, no current land-

628 use policies exist that satisfy all three of these desirable objectives. However, the growing

629 interest in payments for ecosystem services provided by forests in urban areas (Patterson \&

630 Coelho, 2009) may lead to the implementation of effective and novel policy mechanisms.

631 The second objective of this research was to illustrate how stated preference data related

632 to forest owners' land-use decisions could be used to inform spatially explicit projections of

633 potential future urban growth. We accomplished this by applying a Bayesian statistical

634 specification to an established geospatial model designed to predict the potential for future urban

635 development based upon historical development patterns. The Bayesian specification allowed us

636 to incorporate prior knowledge about forest owners' decision-making behavior (i.e., what we

637 learned from the choice experiment model) into the spatially explicit development potential

638 model. The development potential model introduces other important contextual variables such as 
639 development pressure, distance to roads and county-level effects likely to influence where urban

640 growth occurs in the future. By empirically-linking the choice experiment model to the

641 development potential model using a Bayesian approach, we were able to generate spatially-

642 explicit estimates of development potential that, importantly, are informed by primary data

643 collected from the forest owners whose future land-use decisions will affect how and where

644 urbanization occurs throughout the study area. As shown in Figure 6 and described in the results

645 section, the Bayesian parcel-based development potential model fit with informative priors

646 allowed us to better discern heterogeneity and variation across the development potential surface.

647 We were able to fit the parcel-based development potential model to just those forested parcels

648 that could be developed; doing so allowed us to produce more valid estimates of development

649 potential. More explicitly stated, the use of informative priors resulted in a model more finely

650 tuned to the decision-making factors affecting land-use transitions throughout the region. More

651 research on the incorporation of stated preference data into spatially explicit models of

652 development potential is needed. The selective use of informative priors to parameterize urban

653 growth models can be used in a variety of ways. For example, it could be used to better capture

654 the heterogeneity in tastes and preferences among landowners. It could also be used to quantify

655 behavioral responses to specific drivers/inhibitors of urban growth that only occur at specific

656 locations across the urban gradient (e.g., behavioral responses to the development inhibiting

657 invasive plant Japanese knotweed). Future research along these lines would provide a deeper

658 understanding of the dynamic feedbacks that human decision-making processes have on the

659 location and timing of future urban growth.

660 Urban areas are expanding in size and density across the globe, a trend that shows no

661 signs of slowing (Seto et al., 2011, 2012). Consequently, the ecosystem services produced by 
662 agricultural and forested landscapes near urban areas are threatened. Planning for future growth

663 in a sustainable manner will require progressive land-use policies that are both responsive to, and

664 explicitly targeted at, the factors driving individuals' land-use decisions. We have been able

665 develop an understanding of the important factors affecting the land-use decisions of forest

666 owners living around one of the United States' most rapidly growing regions. By linking the

667 results derived from this experiment to a model estimating the potential of land transitions from

668 undeveloped to developed, we have created a more robust conceptualization of the urbanization

669 process. This conceptualization acknowledges urban growth is an aggregate product of human

670 decisions, which are themselves a function of how individuals evaluate competing factors

671 associated with encroaching development. Our research demonstrates rigorously employed social

672 science research can be used to inform spatially explicit projections of where urban growth is

673 most likely to occur in the future. 


\section{Table 1}

Attributes and levels used in experimental design.

\begin{tabular}{ll}
\hline Attribute & \multicolumn{1}{c}{ Levels } \\
\hline $\begin{array}{l}\text { Change in the forest owner's } \\
\text { current property value } \\
\text { (Aproperty_value) }\end{array}$ & $\begin{array}{l}\text { No change } \\
\text { Increase } 10 \% \\
\text { Increase } 20 \%\end{array}$ \\
$\begin{array}{l}\text { Distance from the forest owner's } \\
\text { property to a new development } \\
\text { (distance_to_development) }\end{array}$ & $\begin{array}{l}1000 \text { feet }(304.8 \mathrm{~m}) \\
1 \text { mile }(1.61 \mathrm{~km})\end{array}$ \\
$\begin{array}{l}\text { Whether or not the forest owner's }(3.22 \mathrm{~km}) \\
\text { property qualified for a present } \\
\text { use value program (puv_qualify) }\end{array}$ & $\begin{array}{l}\text { Do not qualify } \\
\text { Qualify }\end{array}$ \\
\hline
\end{tabular}




\section{Table 2}

Characteristics of forest owners and their properties $(n=59)$.

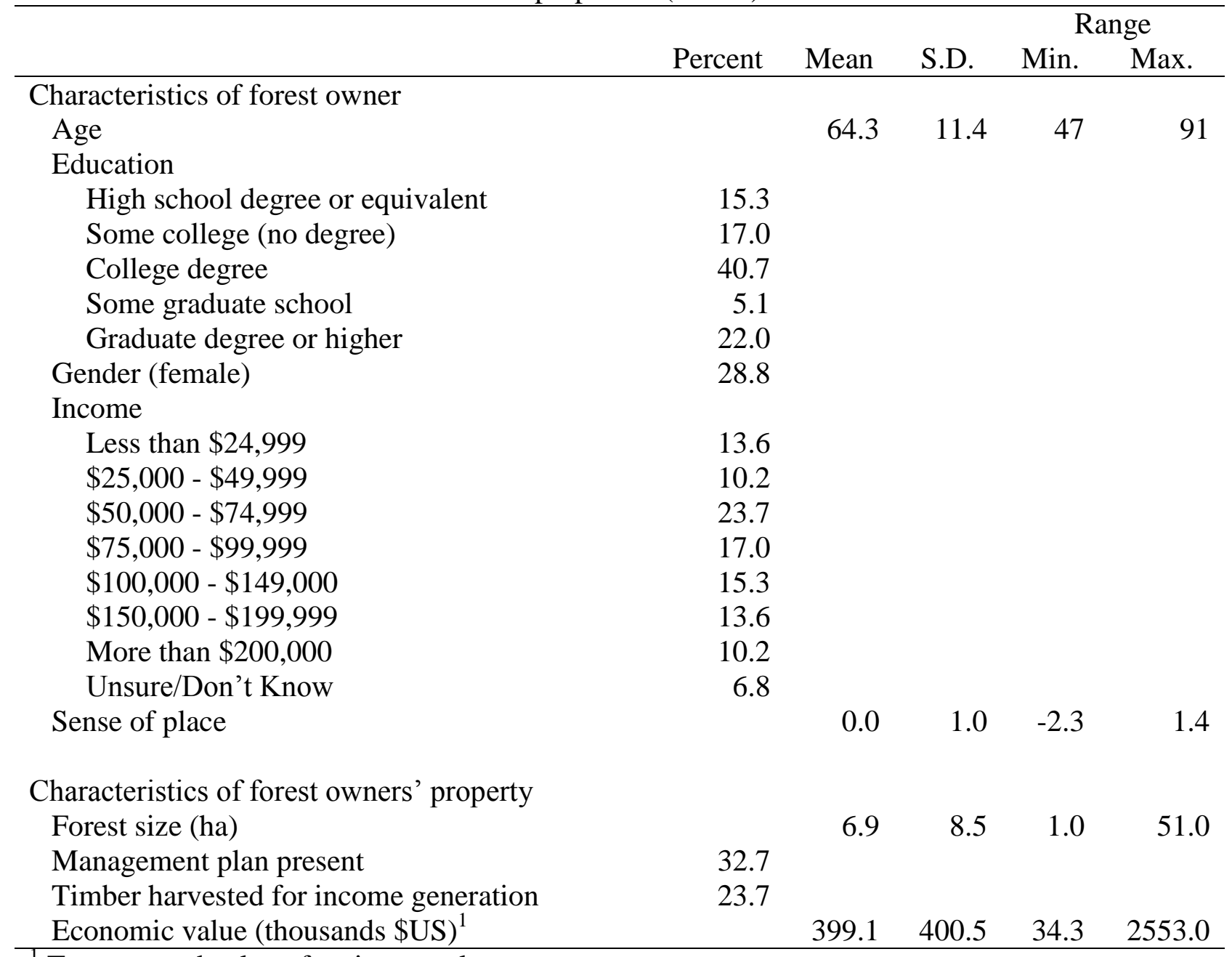

${ }^{1}$ Tax assessed value of entire parcel. 
Table 3

Predictor variables in the development potential model.

$$
\text { Meentemeyer et al.'s (2013) }
$$

\begin{tabular}{|c|c|c|c|c|c|c|c|c|c|}
\hline Variable & & & & & Vrio & & & & \\
\hline $\begin{array}{l}\text { Darlable } \\
\text { Development } \\
\text { pressure }\end{array}$ & \begin{tabular}{l}
\multicolumn{1}{c}{ Description } \\
Number of \\
neighboring \\
developed cells \\
within set search \\
distance weighted \\
by distance
\end{tabular} & \begin{tabular}{l}
\multicolumn{1}{c}{ Base data } \\
Historical \\
development \\
patterns
\end{tabular} & $\begin{array}{l}\text { Year(s } \\
1996, \\
2006\end{array}$ & $\frac{\text { Data source }}{\text { Remote sensing }}$ & \begin{tabular}{l}
\multicolumn{1}{c}{ Variable } \\
Development \\
pressure
\end{tabular} & \begin{tabular}{l}
\multicolumn{1}{c}{ Description } \\
Number of \\
neighboring \\
developed parcels \\
within set search \\
distance weighted by \\
distance
\end{tabular} & \begin{tabular}{l}
\multicolumn{1}{c}{ Base data } \\
Historical \\
development \\
patterns
\end{tabular} & $\begin{array}{l}\text { Year(s) } \\
2000, \\
2011\end{array}$ & \begin{tabular}{l}
\multicolumn{1}{c}{ Data source } \\
National Land \\
Cover Database \\
(NLCD)
\end{tabular} \\
\hline $\begin{array}{l}\text { Distance to } \\
\text { interchanges }\end{array}$ & $\begin{array}{l}\text { Distance form } \\
\text { cell center to } \\
\text { nearest } \\
\text { interchange }\end{array}$ & $\begin{array}{l}\text { Primary and } \\
\text { secondary road } \\
\text { networks }\end{array}$ & 1996 & $\begin{array}{l}\text { North Carolina } \\
\text { Dept. of } \\
\text { Transportation }\end{array}$ & $\begin{array}{l}\text { Distance to } \\
\text { roads }\end{array}$ & $\begin{array}{l}\text { Distance from cell } \\
\text { center to nearest road }\end{array}$ & $\begin{array}{l}\text { Primary and } \\
\text { secondary } \\
\text { road networks }\end{array}$ & 1996 & $\begin{array}{l}\text { North Carolina } \\
\text { Dept. of } \\
\text { Transportation }\end{array}$ \\
\hline $\begin{array}{l}\text { Distance to } \\
\text { roads }\end{array}$ & $\begin{array}{l}\text { Distance from } \\
\text { cell center to } \\
\text { nearest road }\end{array}$ & $\begin{array}{l}\text { Primary and } \\
\text { secondary road } \\
\text { networks }\end{array}$ & 1996 & $\begin{array}{l}\text { North Carolina } \\
\text { Dept. of } \\
\text { Transportation }\end{array}$ & $\begin{array}{l}\text { Distance to new } \\
\text { development }\end{array}$ & $\begin{array}{l}\text { Distance from cell } \\
\text { center to new } \\
\text { development }\end{array}$ & $\begin{array}{l}\text { Historical } \\
\text { development } \\
\text { patterns }\end{array}$ & $\begin{array}{l}2000, \\
2011\end{array}$ & NLCD \\
\hline Land cover & $\begin{array}{l}\text { Lands designated } \\
\text { as forest or } \\
\text { farmland }\end{array}$ & $\begin{array}{l}\text { LiDAR } \\
\text { vegetation } \\
\text { height; } \\
\text { Landsat TM } \\
\text { imagery }\end{array}$ & $\begin{array}{l}1996 \\
2006\end{array}$ & $\begin{array}{l}\text { Charlotte- } \\
\text { Mecklenburg } \\
\text { County Storm } \\
\text { Water Services; } \\
\text { US Geological } \\
\text { Survey }\end{array}$ & Property value & $\begin{array}{l}\text { Property values from } \\
\text { parcel data }\end{array}$ & $\begin{array}{l}\text { North } \\
\text { Carolina } \\
\text { County parcel } \\
\text { data }\end{array}$ & 2015 & $\begin{array}{l}\text { North Carolina } \\
\text { County parcel } \\
\text { data (NC } \\
\text { Onemap) }\end{array}$ \\
\hline $\begin{array}{l}\text { Development } \\
\text { pressure } \times \\
\text { land cover }\end{array}$ & $\begin{array}{l}\text { Interaction } \\
\text { between } \\
\text { development } \\
\text { pressure and land } \\
\text { cover }\end{array}$ & $\mathrm{n} / \mathrm{a}$ & $\begin{array}{l}1996 \\
2006\end{array}$ & $\mathrm{n} / \mathrm{a}$ & $\begin{array}{l}\text { Qualification } \\
\text { for North } \\
\text { Carolina's } \\
\text { present-use } \\
\text { value program }\end{array}$ & $\begin{array}{l}\text { Parcels of } \\
\text { contiguously forested } \\
\text { land that is greater or } \\
\text { equal to the } \\
\text { minimum required to } \\
\text { qualify for the } \\
\text { present-use value } \\
\text { program ( } 20 \text { acres) }\end{array}$ & $\begin{array}{l}\text { Land Cover } \\
\text { data identified } \\
\text { as forested }\end{array}$ & 2011 & NLCD \\
\hline
\end{tabular}




\section{Table 4}

Results of hierarchical Bayesian logistic regression.

95\% Cred.

Interval

\begin{tabular}{|c|c|c|c|c|c|}
\hline Independent variables (fixed-effects) & $\begin{array}{c}\text { Posterior } \\
\text { mean }\end{array}$ & L.B. & U.B. & $\begin{array}{c}\text { Effective } \\
\text { sample size }\end{array}$ & $\mathrm{pMCMC}^{a}$ \\
\hline $\begin{array}{l}\text { Choice attributes } \\
\text { Increased Property value } \\
\text { (Aproperty_value) } \\
\text { Levels } \\
\quad \text { No change } \\
\quad+10 \% \text { increase } \\
+25 \% \text { increase }\end{array}$ & 1.719 & 1.340 & 2.090 & 1482 & $5.0 \mathrm{e}^{-5}$ \\
\hline $\begin{array}{l}\text { New development nearby } \\
\text { (distance_to_development) } \\
\text { Levels } \\
1000 \mathrm{ft}(305 \mathrm{~m}) \\
\text { One mile }(1.6 \mathrm{~km}) \\
\text { Two miles }(3.2 \mathrm{~km})\end{array}$ & -0.446 & -0.814 & -0.099 & 3344 & 0.013 \\
\hline $\begin{array}{l}\text { Qualify for present-use value } \\
\text { program (puv_qualify) } \\
\frac{\text { Levels }}{\text { Do not qualify }} \\
\text { Qualify }\end{array}$ & -0.251 & -0.799 & 0.286 & 3410 & 0.357 \\
\hline Characteristics of the forest owner or & ir property & & & & \\
\hline $\begin{array}{l}\text { Age } \\
\text { Income } \\
\text { Sense of place } \\
\text { Forested acres }\end{array}$ & $\begin{array}{r}-0.074 \\
0.053 \\
-0.692 \\
-0.202\end{array}$ & $\begin{array}{l}-0.158 \\
-0.312 \\
-1.628 \\
-1.266\end{array}$ & $\begin{array}{l}0.003 \\
0.419 \\
0.193 \\
0.852\end{array}$ & $\begin{array}{l}1577 \\
2267 \\
1568 \\
2883\end{array}$ & $\begin{array}{l}0.062 \\
0.763 \\
0.117 \\
0.699\end{array}$ \\
\hline $\begin{array}{l}\text { Hierarchical (random) effects } \\
\text { Respondent }\end{array}$ & 7.795 & 2.955 & 13.710 & 207 & $\mathrm{n} / \mathrm{a}$ \\
\hline
\end{tabular}

$n=59$ (354 discrete choices)

MCMC iterations $=200,000$

Burn-in $=10,000$

${ }^{a}$ Probability the posterior mean is different from zero. 
Table 5

Results of hierarchical development potential model fit to data derived from pixels.

\begin{tabular}{|c|c|c|c|c|c|}
\hline Independent variables (random-effects) & Posterior mean & Standard Error & $\begin{array}{c}\text { Effective } \\
\text { sample size }\end{array}$ & $\mathrm{pMCMC}^{a}$ & Coef. \\
\hline idh (Development pressure: County) & 0.004 & - & 871.4 & - & 0.004 \\
\hline Development pressure: Cabarrus & -0.009 & - & - & - & -0.009 \\
\hline Development pressure: Iredell & -0.017 & - & - & - & -0.017 \\
\hline Development pressure: Mecklenburg & -0.019 & - & - & - & -0.019 \\
\hline Development pressure: Rowan & 0.007 & - & - & - & 0.007 \\
\hline Development pressure: Stanley & 0.043 & - & - & - & 0.043 \\
\hline Development pressure: Union & -0.006 & - & - & - & -0.006 \\
\hline \multicolumn{6}{|l|}{ Independent variables (fixed-effects) } \\
\hline \multicolumn{6}{|l|}{ County-specific intercepts } \\
\hline Intercept (Cabarrus county) & -0.051 & 0.003 & 4526 & 0.842 & -0.051 \\
\hline Iredell county & -0.624 & 0.004 & 4952 & $0.032 *$ & -0.675 \\
\hline Mecklenburg county & 1.377 & 0.004 & 4508 & $<6 \mathrm{e}^{-05 * * *}$ & 1.326 \\
\hline Rowan county & -1.662 & 0.005 & 3545 & $<6 \mathrm{e}^{-05 * * *}$ & -1.713 \\
\hline Stanley county & -3.126 & 0.017 & 951 & $<6 \mathrm{e}^{-05 * * *}$ & -3.177 \\
\hline Union county & -0.335 & 0.003 & 5104 & 0.200 & -0.386 \\
\hline \multicolumn{6}{|l|}{ Landscape variables } \\
\hline Distance to roads & -0.298 & 0.002 & 3326 & $0.019^{*}$ & -0.298 \\
\hline Landcover $($ Forest $=1 /$ Farmland $=0)$ & 0.264 & 0.002 & 4002 & 0.094 & 0.264 \\
\hline Development pressure & 0.185 & 0.001 & 4449 & $0.001 * *$ & 0.185 \\
\hline \multicolumn{6}{|l|}{ Variables affecting forest owners' decisions } \\
\hline Distance to new development & -9.120 & 0.101 & 3484 & 0.124 & -9.120 \\
\hline Property value & 0.030 & 0.001 & 927 & $0.004 * *$ & 0.030 \\
\hline Qualify for present-use value program & -3.140 & 0.012 & 1074 & $<6 \mathrm{e}^{-05 * * *}$ & -3.140 \\
\hline
\end{tabular}
$n=1,724$

MCMC iterations $=200,000$

Burn-in $=20,000$

${ }^{a}$ Probability the posterior mean is different from zero. 
Table 6

Results of hierarchical development potential model fit to data derived from parcels (using non-informative priors and applied spatially to all parcels).

\begin{tabular}{|c|c|c|c|c|c|}
\hline Independent variables (random-effects) & Posterior mean & Standard Error & $\begin{array}{c}\text { Effective } \\
\text { sample size }\end{array}$ & $\mathrm{pMCMC}^{a}$ & Coef. \\
\hline idh (Development pressure: County) & 0.006 & - & 1416 & - & 0.004 \\
\hline Development pressure: Cabarrus & -0.015 & - & - & - & 0.118 \\
\hline Development pressure: Iredell & 0.007 & - & - & - & 0.140 \\
\hline Development pressure: Mecklenburg & -0.055 & - & - & - & 0.078 \\
\hline Development pressure: Rowan & 0.013 & - & - & - & 0.146 \\
\hline Development pressure: Stanley & 0.053 & - & - & - & 0.186 \\
\hline Development pressure: Union & -0.001 & - & - & - & 0.132 \\
\hline \multicolumn{6}{|l|}{ Independent variables (fixed-effects) } \\
\hline \multicolumn{6}{|l|}{ County-specific intercepts } \\
\hline Intercept (Cabarrus county) & 0.648 & 0.004 & 4477 & $0.011 *$ & 0.648 \\
\hline Iredell county & -0.822 & 0.004 & 4984 & $0.005^{*}$ & -0.174 \\
\hline Mecklenburg county & 1.646 & 0.004 & 4094 & $<6 \mathrm{e}-05 * * *$ & 2.294 \\
\hline Rowan county & -1.667 & 0.600 & 3769 & $<6 \mathrm{e}-05 * * *$ & -1.019 \\
\hline Stanley county & -3.272 & 0.015 & 1190 & $<6 \mathrm{e}-05^{* * *} *$ & -2.624 \\
\hline Union county & -0.346 & 0.004 & 5004 & 0.182 & 0.302 \\
\hline \multicolumn{6}{|l|}{ Landscape variables } \\
\hline Distance to roads & -0.498 & 0.002 & 3648 & $<6 \mathrm{e}^{-05 * * *}$ & -0.498 \\
\hline Landcover $($ Forest $=1 /$ Farmland $=0)$ & -0.087 & 0.003 & 4108 & 0.644 & -0.087 \\
\hline Development pressure & 0.133 & 0.002 & 8395 & $0.004 * *$ & 0.133 \\
\hline \multicolumn{6}{|l|}{ Variables affecting forest owners' decisions } \\
\hline Distance to new development & -1.889 & 0.010 & 3769 & $0.004 * *$ & -1.889 \\
\hline Property value & 0.033 & 0.001 & 1037 & $0.002 * *$ & 0.033 \\
\hline Qualify for present-use value program & -3.208 & 0.015 & 842 & $<6 \mathrm{e}^{-05 * * *}$ & -3.208 \\
\hline
\end{tabular}
$n=1,724$

MCMC iterations $=200,000$

Burn-in = 20,000

${ }^{a}$ Probability the posterior mean is different from zero. 
Table 7

Results of hierarchical development potential model fit to data derived from parcels (using priors informed by the choice experiment and applied spatially to only qualifying non-industrial private forest parcels).

\begin{tabular}{|c|c|c|c|c|c|}
\hline Independent variables (random-effects) & Posterior mean & Standard Error & $\begin{array}{c}\text { Effective } \\
\text { sample size }\end{array}$ & $\mathrm{pMCMC}^{a}$ & Coef. \\
\hline idh (Development pressure: County) & 0.006 & - & 1416 & - & 0.006 \\
\hline Development pressure: Cabarrus & -0.015 & - & - & - & 0.117 \\
\hline Development pressure: Iredell & 0.008 & - & - & - & 0.140 \\
\hline Development pressure: Mecklenburg & -0.056 & - & - & - & 0.076 \\
\hline Development pressure: Rowan & 0.012 & - & - & - & 0.144 \\
\hline Development pressure: Stanley & 0.053 & - & - & - & 0.185 \\
\hline Development pressure: Union & -0.001 & - & - & - & 0.131 \\
\hline \multicolumn{6}{|l|}{ Independent variables (fixed-effects) } \\
\hline \multicolumn{6}{|l|}{ County-specific intercepts } \\
\hline Intercept (Cabarrus county) & 0.667 & 0.003 & 5442 & $0.003 * *$ & 0.667 \\
\hline Iredell county & -0.835 & 0.004 & 5243 & $0.001 *$ & -0.168 \\
\hline Mecklenburg county & 1.640 & 0.004 & 4266 & $<6 \mathrm{e}-05^{*} * *$ & 2.307 \\
\hline Rowan county & -1.675 & 0.005 & 3936 & $<6 \mathrm{e}-05 * * *$ & -1.008 \\
\hline Stanley county & -3.273 & 0.011 & 1587 & $<6 \mathrm{e}-05^{* * *} *$ & -2.606 \\
\hline Union county & -0.349 & 0.003 & 5855 & 0.144 & 0.318 \\
\hline \multicolumn{6}{|l|}{ Landscape variables } \\
\hline Distance to roads & -0.491 & 0.002 & 3785 & $<6 \mathrm{e}^{-05 * * *}$ & -0.491 \\
\hline Landcover $($ Forest $=1 /$ Farmland $=0)$ & -0.079 & 0.003 & 4485 & 0.658 & -0.079 \\
\hline Development pressure & 0.132 & 0.001 & 8869 & $0.005 * *$ & 0.132 \\
\hline \multicolumn{6}{|l|}{ Variables affecting forest owners' decisions } \\
\hline Distance to new development & -2.019 & 0.008 & 5168 & $<6 \mathrm{e}^{-05 * * *}$ & -2.019 \\
\hline Property value & 0.034 & 0.001 & 965 & $0.004 * *$ & 0.034 \\
\hline Qualify for present-use value program & -3.228 & 0.012 & 1084 & $<6 \mathrm{e}^{-05 * * *}$ & -3.228 \\
\hline
\end{tabular}

$n=1,724$

MCMC iterations $=200,000$

Burn-in $=20,000$

${ }^{a}$ Probability the posterior mean is different from zero. 
Table S1

Forest owners' responses to the 12-item sense of place scale.

\begin{tabular}{|c|c|c|c|c|c|c|c|c|}
\hline Statement item & $\begin{array}{c}\text { Completely } \\
\text { disagree } \\
(\%)\end{array}$ & $\begin{array}{c}\text { Somewhat } \\
\text { disagree } \\
(\%)\end{array}$ & $\begin{array}{c}\text { Neither } \\
\text { agree nor } \\
\text { disagree } \\
(\%)\end{array}$ & $\begin{array}{c}\text { Somewhat } \\
\text { agree } \\
(\%)\end{array}$ & $\begin{array}{c}\text { Completely } \\
\text { agree } \\
(\%)\end{array}$ & Mean & S.D. & $\begin{array}{c}\text { Factor } \\
\text { Loading }\end{array}$ \\
\hline $\begin{array}{l}\text { Everything about my wooded land is a reflection } \\
\text { of me }\end{array}$ & $\begin{array}{c}9 \\
(16.7)\end{array}$ & $\begin{array}{c}9 \\
(16.7)\end{array}$ & $\begin{array}{c}15 \\
(27.8)\end{array}$ & $\begin{array}{c}7 \\
(13.0)\end{array}$ & $\begin{array}{c}14 \\
(25.9)\end{array}$ & 2.83 & 1.65 & 0.68 \\
\hline $\begin{array}{l}\text { My wooded land says very little about who I am } \\
\text { (reverse coded) }\end{array}$ & $\begin{array}{c}19 \\
(36.5)\end{array}$ & $\begin{array}{c}10 \\
(19.2)\end{array}$ & $\begin{array}{c}15 \\
(28.8)\end{array}$ & $\begin{array}{c}1 \\
(1.9)\end{array}$ & $\begin{array}{c}7 \\
(13.5)\end{array}$ & 2.05 & 1.50 & $-^{a}$ \\
\hline $\begin{array}{l}\text { I feel that I can really be myself when I am on } \\
\text { my wooded land }\end{array}$ & $\begin{array}{c}5 \\
(8.9)\end{array}$ & $\begin{array}{c}1 \\
(1.8)\end{array}$ & $\begin{array}{c}16 \\
(28.6)\end{array}$ & $\begin{array}{c}10 \\
(17.9)\end{array}$ & $\begin{array}{c}24 \\
(42.9)\end{array}$ & 3.58 & 1.56 & 0.73 \\
\hline My wooded land reflects the type of person I am & $\begin{array}{c}6 \\
(11.1)\end{array}$ & $\begin{array}{c}8 \\
(14.8)\end{array}$ & $\begin{array}{c}13 \\
(24.1)\end{array}$ & $\begin{array}{c}15 \\
(27.8)\end{array}$ & $\begin{array}{c}12 \\
(22.2)\end{array}$ & 3.02 & 1.59 & 0.81 \\
\hline I feel relaxed when I am on on my wooded land & $\begin{array}{c}2 \\
(3.5)\end{array}$ & $\begin{array}{c}4 \\
(7.0)\end{array}$ & $\begin{array}{c}7 \\
(12.3)\end{array}$ & $\begin{array}{c}16 \\
(28.1)\end{array}$ & $\begin{array}{c}28 \\
(49.1)\end{array}$ & 3.92 & 1.41 & 0.68 \\
\hline I feel happiest when I am on my wooded land & $\begin{array}{c}4 \\
(7.1)\end{array}$ & $\begin{array}{c}5 \\
(8.9)\end{array}$ & $\begin{array}{c}12 \\
(21.4)\end{array}$ & $\begin{array}{c}15 \\
(26.8)\end{array}$ & $\begin{array}{c}20 \\
(35.7)\end{array}$ & 3.50 & 1.52 & 0.85 \\
\hline My wooded land is my favorite place to be & $\begin{array}{c}5 \\
(8.9)\end{array}$ & $\begin{array}{c}6 \\
(10.7)\end{array}$ & $\begin{array}{c}16 \\
(28.6)\end{array}$ & $\begin{array}{c}11 \\
(19.6)\end{array}$ & $\begin{array}{c}18 \\
(32.1)\end{array}$ & 3.32 & 1.54 & 0.80 \\
\hline $\begin{array}{l}\text { I really miss my wooded land when I am away } \\
\text { from it for too long }\end{array}$ & $\begin{array}{c}8 \\
(16.0)\end{array}$ & $\begin{array}{c}5 \\
(10.0)\end{array}$ & $\begin{array}{c}16 \\
(32.0)\end{array}$ & $\begin{array}{c}10 \\
(20.0)\end{array}$ & $\begin{array}{c}11 \\
(22.0)\end{array}$ & 2.68 & 1.72 & 0.76 \\
\hline $\begin{array}{l}\text { My wooded land is the best place for doing the } \\
\text { things that I enjoy most }\end{array}$ & $\begin{array}{c}5 \\
(9.3)\end{array}$ & $\begin{array}{c}10 \\
(18.5)\end{array}$ & $\begin{array}{c}18 \\
(33.3)\end{array}$ & $\begin{array}{c}9 \\
(16.7)\end{array}$ & $\begin{array}{c}12 \\
(22.2)\end{array}$ & 2.92 & 1.54 & 0.89 \\
\hline $\begin{array}{l}\text { For doing the things that I enjoy most, no other } \\
\text { place can compare to my wooded land }\end{array}$ & $\begin{array}{c}9 \\
(16.7)\end{array}$ & $\begin{array}{c}14 \\
(25.9)\end{array}$ & $\begin{array}{c}16 \\
(29.6)\end{array}$ & $\begin{array}{c}8 \\
(14.8)\end{array}$ & $\begin{array}{c}7 \\
(13.0)\end{array}$ & 2.53 & 1.47 & 0.71 \\
\hline $\begin{array}{l}\text { My wooded land is not a good place to do the } \\
\text { things I most like to do (reverse coded) }\end{array}$ & $\begin{array}{c}27 \\
(50.0)\end{array}$ & $\begin{array}{c}16 \\
(29.6)\end{array}$ & $\begin{array}{c}5 \\
(9.3)\end{array}$ & $\begin{array}{c}4 \\
(7.4)\end{array}$ & $\begin{array}{c}2 \\
(3.7)\end{array}$ & 1.67 & 1.19 & $-^{a}$ \\
\hline $\begin{array}{l}\text { As far as I'm concerned, there are better places } \\
\text { to be than on my wooded land (reverse coded) }\end{array}$ & $\begin{array}{c}22 \\
(40.7)\end{array}$ & $\begin{array}{c}14 \\
(25.9)\end{array}$ & $\begin{array}{c}9 \\
(16.7)\end{array}$ & $\begin{array}{c}5 \\
(9.3)\end{array}$ & $\begin{array}{c}4 \\
(7.4)\end{array}$ & 1.95 & 1.37 & $-^{a}$ \\
\hline
\end{tabular}

Overall scale $\alpha=0.93$

${ }^{a}$ Item dropped due to poor factor loading before assessment of measurement model fit and calculation of sense_of_place factor score. 


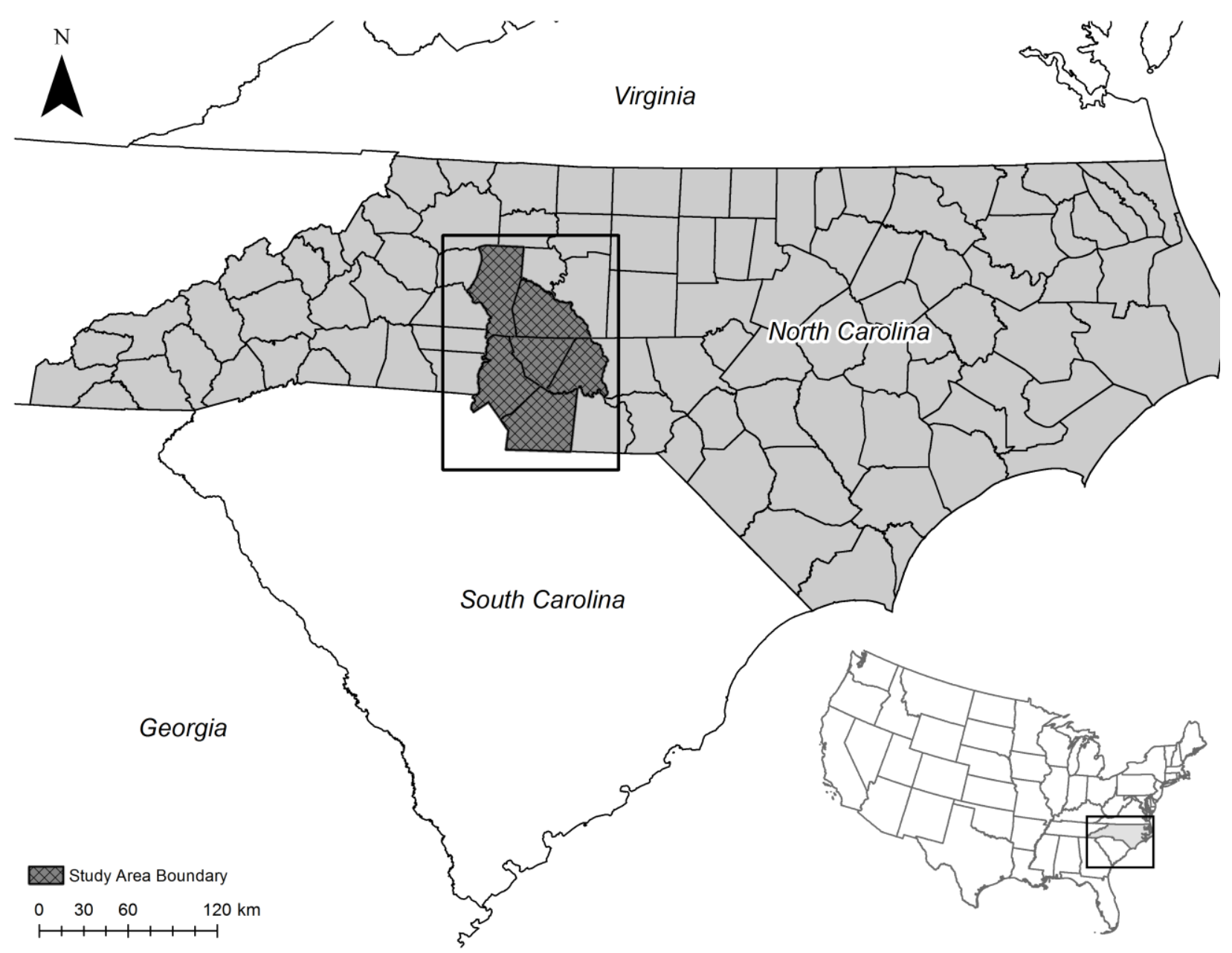

Figure 1. Study area. 


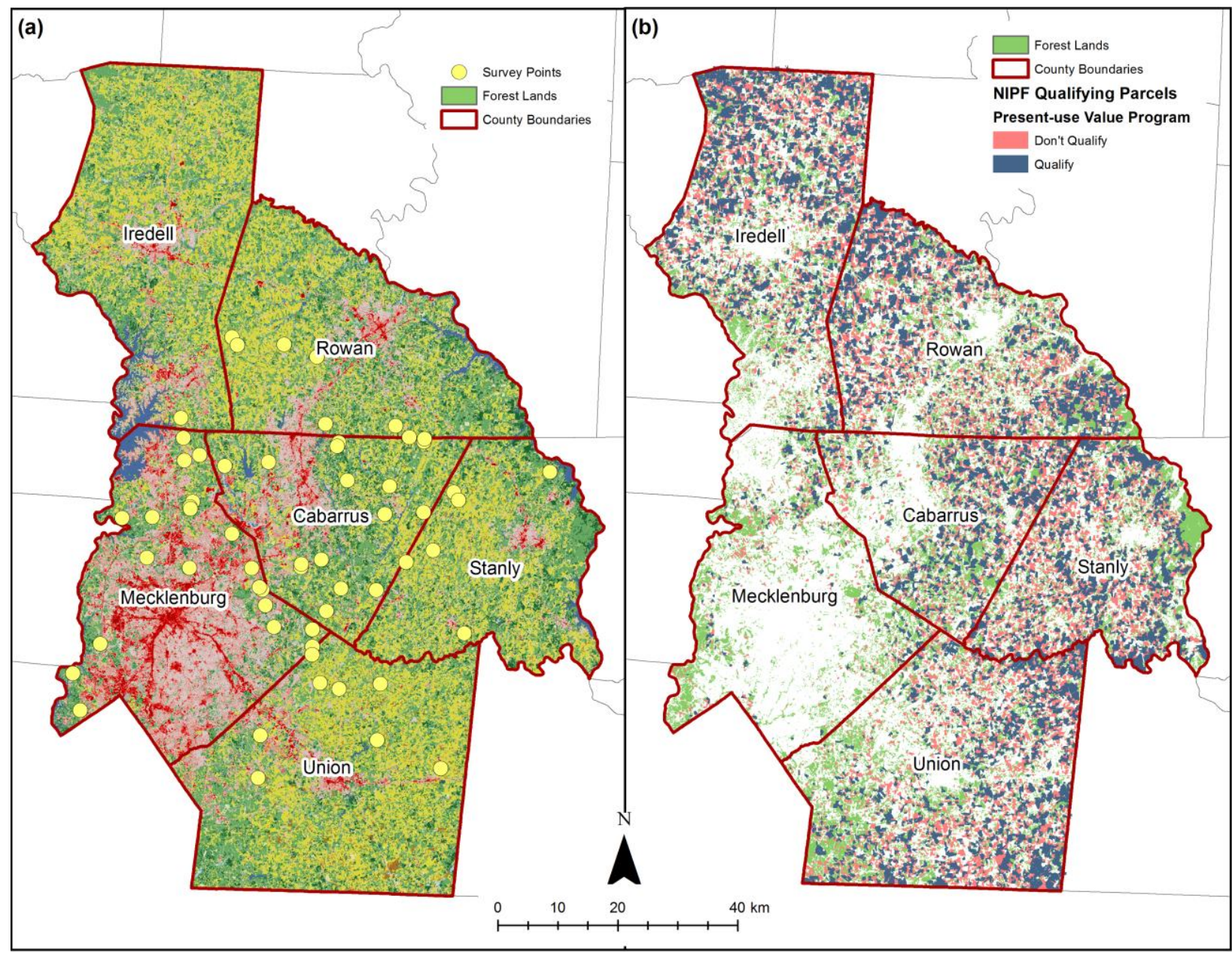

Figure 2. (a) The study area with land cover and survey points. (b) Parcels that comprise the study's sampling frame of forest owners classified by whether or not the parcel qualifies for the present-use value program. 


\section{Part 1. Likelihood of Selling Your Property}

We are interested in the factors that influence individuals' decision to sell or hold their wooded land, including how property values, proximity to new development, and present-use value programs affect woodland owners' decisions, if at all. Here, "new development" refers to clearing of previously undeveloped woodland or farmland in order to build structures or infrastructure. Qualifying for a present-use value program would allow the value of your land to be based on current use as agricultural or forested land, resulting in a substantial reduction in taxes. Note that we are not examining whether or not your land actually qualifies, therefore please ignore your actual present use value status.

To help us understand the importance of these factors, consider each pair of hypothetical conditions below. For each pair please provide two responses: 1 ) which set of conditions would make you more likely to sell your wooded land shown in the attached map and 2) how likely you would be to sell your property under those conditions. Example: In the first pair choose between the first scenario where your property value has increased by $25 \%$, new developments have been started within 1000 feet of your property and your wooded land does not qualify for the present-use value policy AND the second scenario where your property value has increased by $10 \%$, new developments have started within one mile of your property and your wooded land does not qualify for present use value policy.

\begin{tabular}{|c|c|c|c|c|c|}
\hline Pair & $\begin{array}{l}\text { Change in } \\
\text { your current } \\
\text { property } \\
\text { value }\end{array}$ & $\begin{array}{c}\text { Distance from your } \\
\text { property to a new } \\
\text { development }\end{array}$ & $\begin{array}{c}\text { Availability of a } \\
\text { present use value } \\
\text { program }\end{array}$ & $\begin{array}{c}\text { Under which of these } \\
\text { two conditions, would } \\
\text { you be most likely to sell } \\
\text { your property? }\end{array}$ & $\begin{array}{c}\text { Likelihood } \\
\text { of selling }\end{array}$ \\
\hline \multirow{2}{*}{1} & Increase $25 \%$ & 1000 feet & Do not qualify & $\square$ & \multirow{2}{*}{$\%$} \\
\hline & Increase $10 \%$ & One mile & Do not qualify & $\square$ & \\
\hline \multirow{2}{*}{2} & Increase $10 \%$ & One mile & Do not qualify & $\square$ & \multirow{2}{*}{$\ldots$} \\
\hline & No Change & Two miles & Do not qualify & $\square$ & \\
\hline \multirow{3}{*}{3} & & & & & \multirow{3}{*}{ _\% } \\
\hline & Increase $10 \%$ & 1000 feet & Do not qualify & $\square$ & \\
\hline & No Change & One mile & Qualify & $\square$ & \\
\hline \multirow{2}{*}{4} & Increase $25 \%$ & One mile & Qualify & $\square$ & \multirow{2}{*}{$\%$} \\
\hline & No Change & 1000 feet & Qualify & $\square$ & \\
\hline & & & & & \multirow{3}{*}{$-\%$} \\
\hline \multirow{2}{*}{5} & No Change & One mile & Do not qualify & $\square$ & \\
\hline & Increase $10 \%$ & 1000 feet & Qualify & $\square$ & \\
\hline \multirow{2}{*}{6} & No Change & 1000 feet & Do not qualify & $\square$ & \multirow{2}{*}{$\%$} \\
\hline & Increase $10 \%$ & Two miles & Do not qualify & $\square$ & \\
\hline
\end{tabular}

I would not sell my wooded land under any of these circumstances

Figure 3. Survey question 

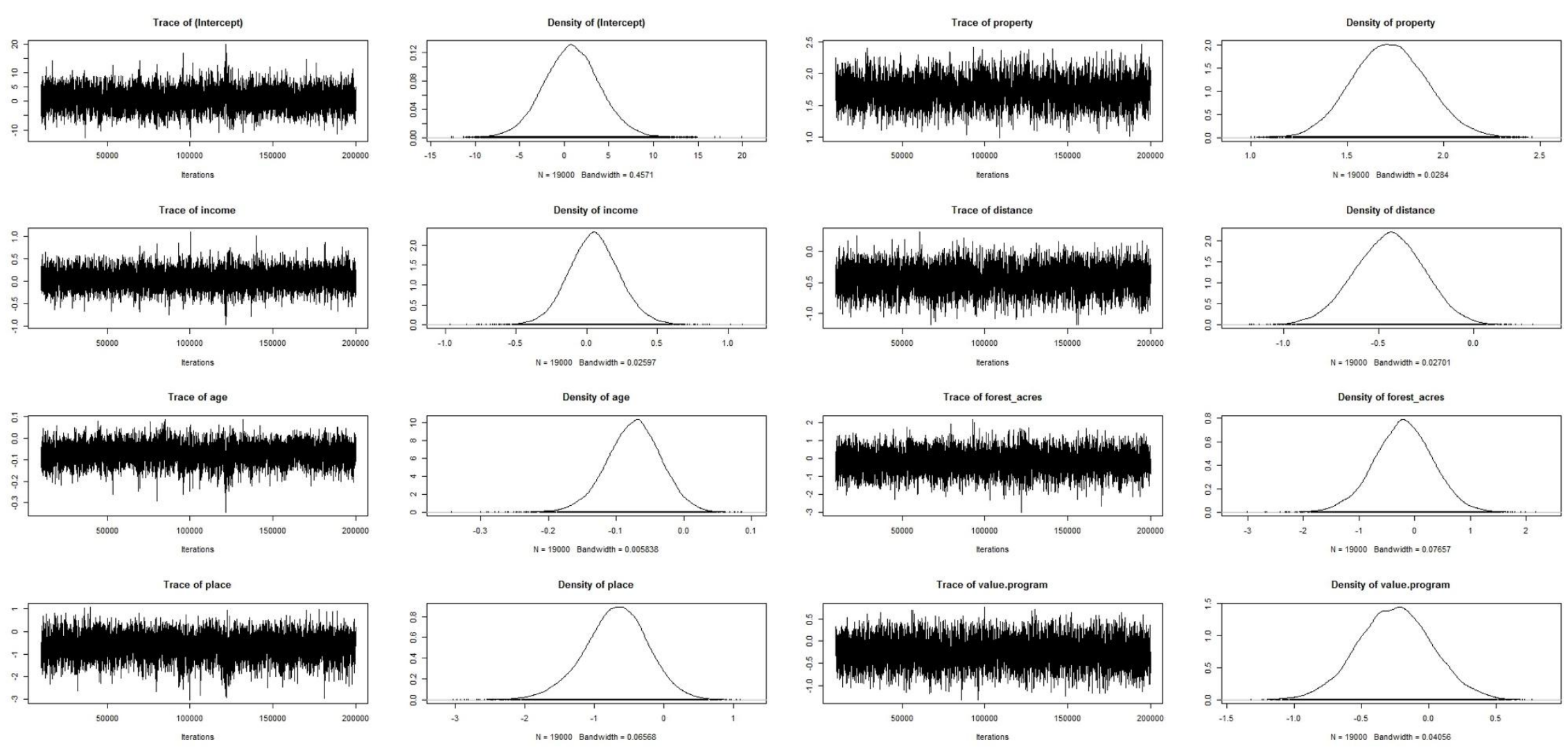

Figure 4. Diagnostic plots for posterior distributions generated from Bayesian estimation of the choice experiment eliciting forest owners' intent to sell their properties. 


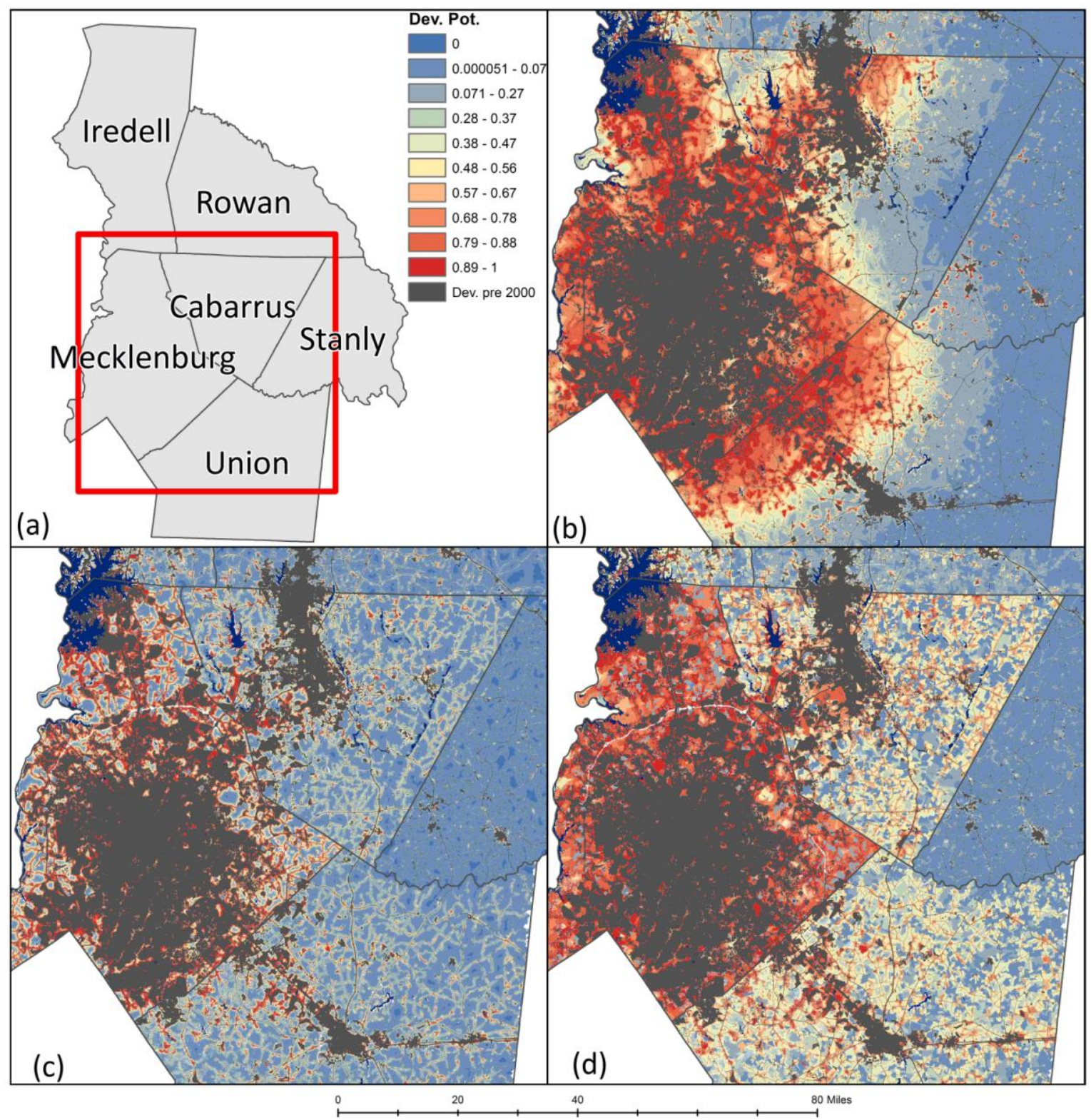

Figure 5. (a) The six county study area in North Carolina with a zoom-in on the focus area. (b) The pixel-based model with the same model and variables used in Meentemeyer et al. (2013). (c) The pixel-based model with the additional predictor variables related to the choice experiment (i.e., property values, distance to new development and qualification for the present use value program). (d) The parcel-based model with the additional predictor variables related to the choice experiment. All models utilized a Bayesian approach with non-informative priors (i.e., for fixed effects this equates to a mean of zero and very large variance, see methods for additional details). 


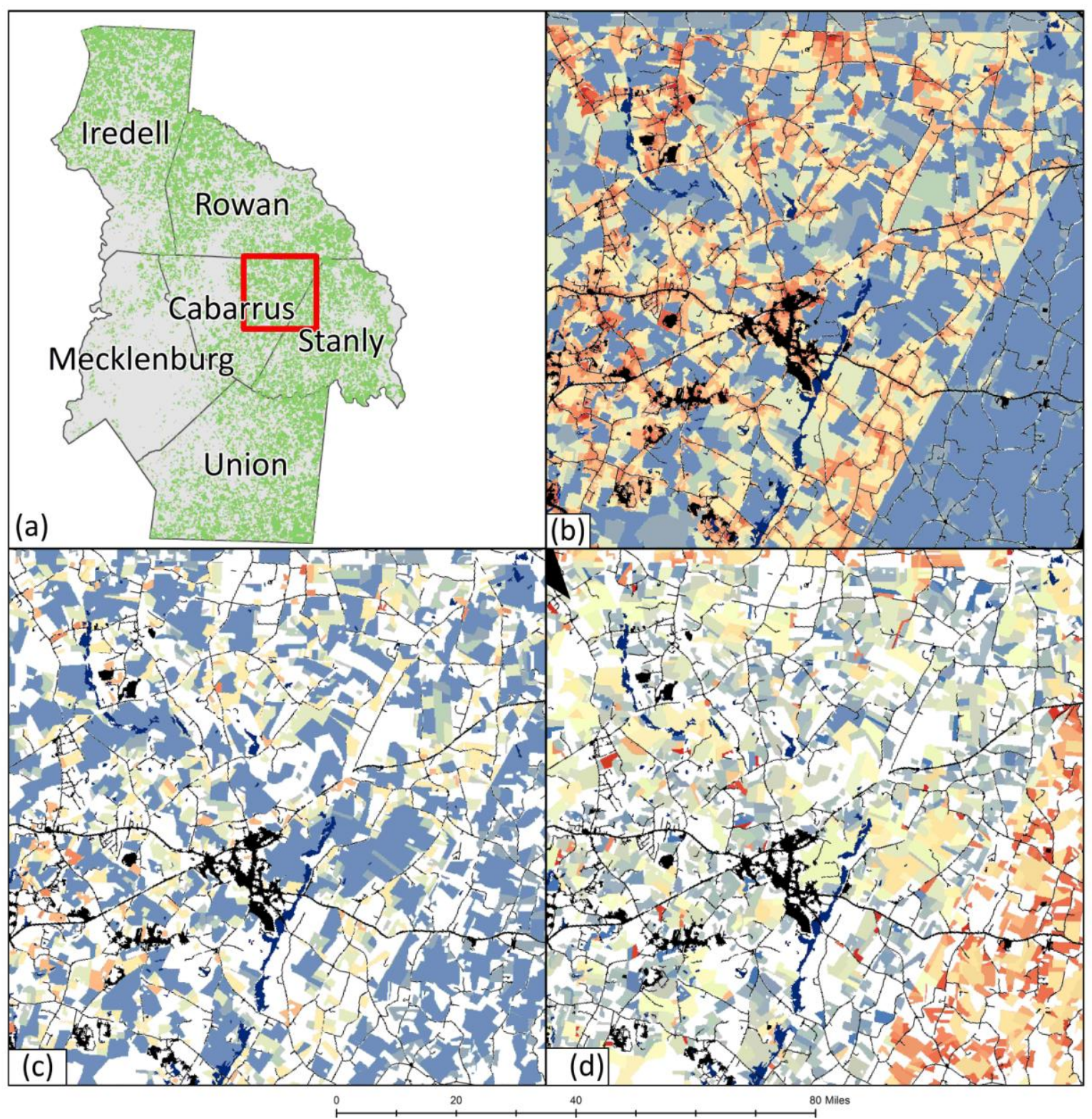

Figure 6. (a) Six county study area with qualifying parcels owned by non-industrial private forest owners shown in green. (b) Results of the parcel-based development potential model fit with non-informative priors (see methods for more details). (c) Results of the parcel-based development potential model fit to only qualifying parcels owned by non-industrial private forest owners - modeled using priors generated by the choice experiment model (see methods for more details). (d) The difference between estimated development potential derived from the parcelbased model fit with non-informative priors and the parcel-based model fit with informative priors generated by the choice experiment model. Warmer colors represent qualifying parcels owned by non-industrial private forest owners that were mapped as having higher development potential when informative priors were used and cooler colors represent parcels owned by nonindustrial private forest owners that were mapped as having lower development potential when informative priors were used. 


\section{References}

Adams, T., \& Turner, J. A. (2012). An investigation into the effects of an emissions trading scheme on forest management and land use in New Zealand. Forest Policy and Economics, 15, 78-90.

Adu-Gyamfi, A. (2012). An overview of compulsory land acquisition in Ghana: Examining its applicability and effects. Environmental Management and Sustainable Development, $1(2), 187$.

Alberti, M. (2010). Maintaining ecological integrity and sustaining ecosystem function in urban areas. Current Opinion in Environmental Sustainability, 2(3), 178-184. https://doi.org/10.1016/j.cosust.2010.07.002

Alig, R. J., Kline, J. D., \& Lichtenstein, M. (2004). Urbanization on the US landscape: Looking ahead in the 21st century. Landscape and Urban Planning, 69(2-3), 219-234. https://doi.org/10.1016/j.landurbplan.2003.07.004

Anderson, J. E. (2012). Agricultural use-value property tax assessment: Estimation and policy issues. Public Budgeting and Finance, 32(4), 71-94.

Angel, S., Parent, J., Civco, D. L., Blei, A., \& Potere, D. (2011). The dimensions of global urban expansion: Estimates and projections for all countries, 2000-2050. Progress in Planning, 75, 53-107. https://doi.org/10.1016/j.progress.2011.04.001

Bastian, C. T., McLeod, D. M., Germino, M. J., Reiners, W. A., \& Blasko, B. J. (2002). Environmental amenities and agricultural land values: a hedonic model using geographic information systems data. Ecological Economics, 40(3), 337-349. https://doi.org/10.1016/S0921-8009(01)00278-6 
BenDor, T., Shoemaker, D. A., Thill, J.-C., Dorning, M. A., \& Meentemeyer, R. K. (2014). A mixed-methods analysis of social-ecological feedbacks between urbanization and forest persistence. Ecology \& Society, 19(3), 3.

Bengston, D. N., Asah, S. T., \& Butler, B. J. (2010). The diverse values and motivations of family forest owners in the United States: An analysis of an open-ended question in the National Woodland Owner Survey. Small-Scale Forestry, 10(3), 339-355. https://doi.org/10.1007/s11842-010-9152-9

Bernardo, J. M., \& Smith, A. F. M. (2000). Bayesian theory. Chichester, United Kingdom: John Wiley \& Sons.

Bhatta, B. (2010). Causes and consequences of urban growth and sprawl. In Analysis of urban growth and sprawl from remote sensing data (pp. 17-36). Springer Berlin Heidelberg. https://doi.org/10.1007/978-3-642-05299-6_2

Blythe, L., \& Brockmann, C. R. (1961). Hornets' nest: The story of Charlotte and Mecklenburg county. Charlotte, NC: Public Library of Charlotte and Mecklenburg county.

Brown, D. G., Johnson, K. M., Loveland, T. R., \& Theobald, D. M. (2005). Rural land-use trends in the conterminous United States, 1950-2000. Ecological Applications, 15(6), 18511863. https://doi.org/10.1890/03-5220

Brown, D. G., Verburg, P. H., Pontius Jr, R. G., \& Lange, M. D. (2013). Opportunities to improve impact, integration, and evaluation of land change models. Current Opinion in Environmental Sustainability, 5(5), 452-457. https://doi.org/10.1016/j.cosust.2013.07.012

Brueckner, J. K. (2000). Urban sprawl: Diagnosis and remedies. International Regional Science Review, 23(2), 160-171. 
Butler, B. J. (2008). Family forest owners of the United States, 2006 (General Technical Report No. NRS-27) (p. 72). Newtown Square, PA: USDA Forest Service, Northern Research Station.

Butler, B. J., Catanzaro, P. F., Greene, J. L., Hewes, J. H., Kilgore, M. A., Kittredge, D. B., ... Tyrrell, M. L. (2012). Taxing family forest owners: Implications of federal and state policies in the United States. Journal of Forestry, 110(7), 371-380.

Butler, B. J., Hewes, J. H., Dickinson, B. J., Andreichzyk, K., Butler, S. M., \& MarkowskiLindsay, M. (2016). Family forest ownership in the United States, 2013: Findings from the USDA Forest Service's National Woodland Owner Survey. Journal of Forestry, 114.

Capozza, D. R., \& Helsley, R. W. (1989). The fundamentals of land prices and urban growth. Journal of Urban Economics, 26(3), 295-306. https://doi.org/10.1016/00941190(89)90003-X

Carlin, B. P., \& Louis, T. A. (2008). Bayesian methods for data analysis (3rd ed.). Boca Raton: Chapman and Hall/CRC.

Casella, G., \& George, E. (1992). Explaining the Gibbs sampler. The American Statistician, 46, $167-174$.

Chavas, J. P., \& Thomas, A. (1999). A dynamic analysis of land prices. American Journal of Agricultural Economics, 81(4), 772-784.

Delbecq, B. A., Kuethe, T. H., \& Borchers, A. M. (2014). Identifying the extent of the urban fringe and its impact on agricultural land values. Land Economics, 90(4), 587-600. https://doi.org/10.3368/le.90.4.587

Denyer-Green, B. (2013). Compulsory purchase and compensation. Taylor \& Francis. 
Dillman, D. A., Smyth, J. D., \& Christian, L. M. (2008). Internet, mail, and mixed-mode surveys: The tailored design method (3rd ed.). New York: Wiley.

Dorning, M. A., Smith, J. W., Shoemaker, D. A., \& Meentemeyer, R. K. (2015). Changing decisions in a changing landscape: How might forest owners in an urbanizing region respond to emerging bioenergy markets? Land Use Policy, 49, 1-10. https://doi.org/10.1016/j.landusepol.2015.06.020

Epstein, R. A. (2013). Private and common property: Liberty, property, and the law. Routledge.

Erickson, D. L., Ryan, R. L., \& De Young, R. (2002). Woodlots in the rural landscape: Landowner motivations and management attitudes in a Michigan (USA) case study. Landscape and Urban Planning, 58, 101-112.

Florida, R., Mellander, C., \& Stolarick, K. (2008). Inside the black box of regional development -- human capital, the creative class, and tolerance. Journal of Economic Geography, 8(5), $615-649$.

Frumkin, H. (2002). Urban sprawl and public health. Public Health Reports, 117, 201-217.

Greene, J. L., Butler, B. J., Catanzaro, P. F., Hewes, J. H., Kilgore, M. A., Kittredge, D. B., ... Tyrrell, M. L. (2014). Family forest owners and federal taxes. Family Forest Owners and Federal Taxes, 38, 219-226.

Guiling, P., Brorsen, B. W., \& Doye, D. (2009). Effect of urban proximity on agricultural land values. Land Economics, 85(2), 252-264. https://doi.org/10.3368/le.85.2.252

Hadfield, J. D. (2010). MCMC methods for multi-response generalized linear mixed models: The MCMC glmm R package. Journal of Statistical Software, 33(2), 1-22.

Hair, J. F., Black, W. C., Babin, B. J., \& Anderson, R. E. (2009). Multivariate Data Analysis (7th ed.). Prentice Hall. 
Hansen, A. J., Knight, R. L., Marzluff, J. M., Powell, S., Brown, K., Gude, P. H., \& Jones, K. (2005a). Effects of exurban development on biodiversity: patterns, mechanisms, and research needs. Ecological Applications, 15(6), 1893-1905. https://doi.org/10.1890/055221

Hansen, A. J., Knight, R. L., Marzluff, J. M., Powell, S., Brown, K., Gude, P. H., \& Jones, K. (2005b). Effects of exurban development on biodiversity: patterns, mechanisms, and research needs. Ecological Applications, 15(6), 1893-1905. https://doi.org/10.1890/055221

Holmes, T. P., \& Boyle, K. J. (2003). Stated preference methods for valuation of forest attributes. In E. Sills \& K. L. Abt (Eds.), Forests in a market economy (pp. 321-340). Dordrecht, Netherlands: Kluwer Academic.

Hosmer, D. W., Lemeshow, S., \& Sturdivant, R. X. (2013). Applied logistic regression (3rd ed.). Hoboken, NJ: John Wiley \& Sons, Inc.

Jorgensen, B. S., \& Stedman, R. C. (2006). A comparative analysis of predictors of sense of place dimensions: Attachment to, dependence on, and identification with lakeshore properties. Journal of Environmental Management, 79(3), 316-327. https://doi.org/10.1016/j.jenvman.2005.08.003

Kilgore, M. A., Snyder, S. A., Eryilmaz, D., Markowski-Lindsay, M. A., Butler, B. J., Kittredge, D. B., ... Andrejczyk, K. (2015). Assessing the relationship between different forms of landowner assistance and family forest owner behaviors and intentions. Journal of Forestry, 113(1), 12-19.

Knudson, C. (2015). Generalized linear mixed models via Monte Carlo Likelihood Approximation. Retrieved from https://cran.r-project.org/web/packages/glmm/glmm.pdf 
Lin, T.-C., \& Lin, S.-T. (2006). Decision-making of property owners and tenants in the face of compulsory purchase. Habitat International, 30(3), 434-447. https://doi.org/10.1016/j.habitatint.2004.12.001

Louviere, J. J., Hensher, D. A., \& Swait, J. D. (2000). Stated choice methods: Analysis and applications. Cambridge, United Kingdom: Cambridge University Press.

Lubowski, R. N., Plantinga, A. J., \& Stavins, R. N. (2006). Land-use change and carbon sinks: Econometric estimation of the carbon sequestration supply function. Journal of Environmental Economics and Management, 51(2), 135-152. https://doi.org/10.1016/j.jeem.2005.08.001

Lubowski, R. N., Plantinga, A. J., \& Stavins, R. N. (2008). What drives land-use change in the United States? A national analysis of landowner decisions. Land Economics, 84(4), 529550. https://doi.org/10.3368/le.84.4.529

Ma, Z., Butler, B. J., Catanzaro, P. F., Greene, J. L., Hewes, J. H., Kilgore, M. A., ... Tyrrell, M. (2014). The effectiveness of state preferential property tax programs in conserving forests: Comparisons, measurements, and challenges. Land Use Policy, 36, 492-499.

Maestas, J. D., Knight, R. L., \& Gilgert, W. C. (2003). Biodiversity across a rural land-use gradient. Conservation Biology, 17(5), 1425-1434. https://doi.org/10.1046/j.15231739.2003.02371.x

Majumdar, I., Laband, D., Teeter, L., \& Butler, B. (2009). Motivations and land-use intentions of nonindustrial private forest landowners: Comparing inheritors to noninheritors. Forest Science, 55(5), 423-432.

McFadden, D. (1973). Conditional logit analysis of qualitative choice behavior. In P. Zarembka (Ed.), Frontiers in econometrics (pp. 105-142). New York: Academic Press. 
Meentemeyer, R. K., Tang, W., Dorning, M. A., Vogler, J. B., Cunniffe, N. J., \& Shoemaker, D. A. (2013). FUTURES: Multilevel simulations of emerging urban-rural landscape structure using a stochastic patch-growing algorithm. Annals of the Association of American Geographers, 103(4), 785-807. https://doi.org/10.1080/00045608.2012.707591

Milburn, L.-A. S., Brown, R., \& Mulley, S. J. (2010). “... Silver in the stars and gold in the morning sun": Non-farm rural landowners' motivations for rural living and attachment to their land. Landscape Research, 35(1), 27-46.

Munn, I. A., Barlow, S. A., Evans, D. L., \& Cleaves, D. (2002). Urbanization's impact on timber harvesting in the south central United States. Journal of Environmental Management, 64(1), 65-76. https://doi.org/10.1006/jema.2001.0504

National Research Council. (2013). Advancing land change modeling: Opportunities and research requirements. Washington, DC: The National Academies Press.

NCOSBM. (2015). County/state population projections. Retrieved December 2, 2015, from http://www.osbm.nc.gov/demog/county-projections

North Carolina Department of Revenue. (2015). Present-use value program guide. Raleigh, NC: North Carolina Department of Revenue.

Nunnally, J. C., \& Bernstein, I. H. (1994). Psychometric theory (3rd ed.). New York: McGrawHill.

Patterson, T. M., \& Coelho, D. L. (2009). Ecosystem services: Foundations, opportunities, and challenges for the forest products sector. Forest Ecology and Management, 257(8), 16371646. https://doi.org/10.1016/j.foreco.2008.11.010 
Plantinga, A. J., Lubowski, R. N., \& Stavins, R. N. (2002). The effects of potential land development on agricultural land prices. Journal of Urban Economics, 52(3), 561-581. https://doi.org/10.1016/S0094-1190(02)00503-X

Polyakov, M., \& Zhang, D. (2008). Property tax policy and land-use change. Land Economics, 84(3), 396-408. https://doi.org/10.3368/le.84.3.396

Poudyal, N. C., \& Hodges, D. G. (2009). Property taxation and rural land values: Their effect on private forestland ownership structure in Texas. Land Use Policy, 26(4), 1100-1105. https://doi.org/10.1016/j.landusepol.2009.01.005

Radeloff, V. C., Hammer, R. B., \& Stewart, S. I. (2005). Rural and suburban sprawl in the U.S. Midwest from 1940 to 2000 and its relation to forest fragmentation. Conservation Biology, 19(3), 793-805. https://doi.org/10.1111/j.1523-1739.2005.00387.x

Rozance, M. A., \& Rabotyagov, S. S. (2014). Washington state small forest landowners: Who intends to develop their forestlands and when. Journal of Forestry, 112(6), 572-580. https://doi.org/10.5849/jof.12-103

Seto, K. C., Dhakal, S., Bigio, A., Blanco, H., Delgado, G. C., Dewar, D., ... Ramaswami, A. (2014). Human settlements, infrastructure and spatial planning. In O. Edenhofer, R. Pichs-Madruga, Y. Sokona, E. Farahani, S. Kadner, K. Seyboth, ... J. C. Minx (Eds.), Climate change 2014: Mitigation of climate change. Contribution of Working Group III to the Fifth Assessment Report of the Intergovernmental Panel on Climate Change (pp. 923-1000). Cambridge, UK and New York: Cambridge University Press.

Seto, K. C., Fragkias, M., Güneralp, B., \& Reilly, M. K. (2011). A meta-analysis of global urban land expansion. PLoS ONE, 6(8), 1-9. https://doi.org/10.1371/journal.pone.002377 
Seto, K. C., Güneralp, B., \& Hutyra, L. R. (2012). Global forecasts of urban expansion to 2030 and direct impacts on biodiversity and carbon pools. Proceedings of the National Academy of Sciences, 109(40), 16083-16088. https://doi.org/10.1073/pnas.1211658109

Silver, E. J., Leahy, J. E., Weiskittel, A. R., Noblet, C. L., \& Kittredge, D. B. (2015). An evidence-based review of timber harvesting behavior among private woodland owners. Journal of Forestry, 113(5), 490-499.

Singh, K. K., Vogler, J. B., Shoemaker, D. A., \& Meentemeyer, R. K. (2012). LiDAR-Landsat data fusion for large-area assessment of urban land cover: Balancing spatial resolution, data volume and mapping accuracy. ISPRS Journal of Photogrammetry and Remote Sensing, 74, 110-121. https://doi.org/10.1016/j.isprsjprs.2012.09.009

Smith, J. W., Dorning, M. A., Shoemaker, D. A., Méley, A., Dupey, L. N., \& Meentemeyer, R. K. (2016). Payments for carbon storage to alleviate development pressure in a rapidly urbanizing region. Forest Science.

Stein, S. M., McRoberts, R. E., Alig, R. J., Nelson, M. D., Theobald, D. M., Eley, M., ... Carr, M. (2005). Forests on the edge: Housing development on America's private forests (General Technical Report No. PNW-GTR-636). Portland, OR: USDA Forest Service, Pacific Northwest Research Station.

Tanner, M. A., \& Wong, W. H. (1987). The calculation of posterior distributions by data augmentation. Journal of the American Statistical Association, 82(398), 528-540. https://doi.org/10.1080/01621459.1987.10478458

Tisdale, H. (1942). The process of urbanization. Social Forces, 20(3), 311-316.

U.S. Census Bureau. (2015). State and county quickfacts. Retrieved December 2, 2015, from http://quickfacts.census.gov/qfd/states/37000.html 
Verburg, P. H., Crossman, N., Ellis, E. C., Heinimann, A., Hostert, P., Mertz, O., ... Zhen, L. (2015). Land system science and sustainable development of the earth system: A global land project perspective. Anthropocene, 12, 29-41. https://doi.org/10.1016/j.ancene.2015.09.004

Verburg, P. H., Dearing, J. A., Dyke, J. G., van der Leeuw, S., Seitzinger, S., Steffen, W., \& Syvitski, J. (2016). Methods and approaches to modelling the Anthropocene. Global Environmental Change, 39, 328-340. https://doi.org/10.1016/j.gloenvcha.2015.08.007

Wear, D. N., \& Newman, D. H. (2004). The speculative shadow over timberland values in the US South. Journal of Forestry, 102(8), 25-31.

Williams, E. D., Gottfried, R. R., Brockett, C. D., \& Evans, J. P. (2004). An integrated analysis of the effectiveness of Tennessee's Forest Greenbelt Program. Landscape and Urban Planning, 69(2-3), 287-297. https://doi.org/10.1016/j.landurbplan.2003.08.008 